\title{
Latest Triassic climate humidification and kaolinite formation (Western Carpathians, Tatric Unit of the Tatra Mts.)
}

\author{
Otília LINTNEROVÁ ${ }^{1}$, Jozef MICHALÍK ${ }^{2, *}$, Peter UHLÍK ${ }^{1}$, Ján SOTÁK ${ }^{3}$ \\ and Zuzana WEISSOVÁ
}

1 Comenius University, Department of Economic Geology, Faculty of Science, Mlynská dolina, pav. G, 84215 Bratislava, Slovakia

2 Geological Institute, Slovak Academy of Sciences, Dúbravská 9, PO Box 106, 84005 Bratislava, Slovakia

3 Geological Institute, Slovak Academy of Sciences, Ďumbierska 1, 97401 Banská Bystrica, Slovakia

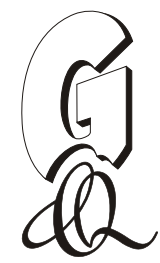

Lintnerová O., Michalík J., Uhlík P., Soták J. and Weissová Z. (2013) Latest Triassic climate humidification and kaolinite formation (Western Carpathians, Tatric Unit of the Tatra Mts.). Geological Quarterly, 57 (4): 701-728, doi: 10.7306/gq.1123

\begin{abstract}
The Tomanová Formation, of Rhaetian age, overlying the Norian Carpathian Keuper in the Tatra Mts. is built of cyclic parasequences of mudstones and sandstones. Quartz (15 to $70 \mathrm{wt} \%$ ), kaolinite (13 to $46 \mathrm{wt} . \%$ ) and 2:1 Al dioctahedral phyllosilicates (dioct 2:1: muscovite, illite, illite/smectite: 5 to $39 \mathrm{wt} . \%$ ) represent the major mineral phase. The kaolinite/dioct $2: 1$ ratio decreases upwards in the section (from 4.3 to 0.5 ) and signals variability in weathering/erosion intensity and changing water salinity. Major and trace elements (LILE, HSFS, REE) indicate a uniform source - felsic rocks located probably in the Vindelician Highlands. The sedimentation rate $(83 \mathrm{~mm} / \mathrm{ky})$ was controlled by climate. Alternation of dry and humid periods is refered by sedimentary textures and by maturity of quartz (aeolian vs. fluvial grains), and organic matter content and composition $\left(\mathrm{C}_{\text {org }}\right.$ and $\delta^{13} \mathrm{C}_{\text {org }}$ ). Authigenic siderite or bethierine documents wet and reduced conditions in the upper part of the Tomanová Formation. The sedimention rate of the marine Dudzinec Formation attained $25 \mathrm{~mm} / \mathrm{ka}$ and the character of cycles preserved in the sequence is similar as that of the Tomanová Formation (fining upwards parasequences). However, the different clay mineralogy, the recycled character of the silicates, the different $\delta^{13} \mathrm{C}_{\text {org }}$ and elevated imput of carbonate detritus with specific $\mathrm{C}$ and $\mathrm{O}$ isotopic patterns document a discontinuity in the section. The transgressive character of the Dudzinec Fm. was deduced from the stratigraphic distribution and environmental characteristics of the benthic foraminifera present. Involutinids and spirillinids dominate in the lower part, endothyrinids govern the middle part, and in the upper part nodosariids and Ammodiscus-type microfauna occur. These age-diagnostic microfossils indicate a late Rhaetian age. Sea level rise in the Tatric Zone triggered by thermal expansion of the Central Atlantic Rift was gradual, being affected by input of terrestrial clastic sediment both by freshwater and by wind. The Tatric Triassic sequence in the Western Carpathians helps understanding of the development of sedimentation, palaeoclimate (kaolinite weathering), and palaeogeography of the northernmost Tethyan Domain.
\end{abstract}

Key words: sedimentology, foraminifers, clay minerals, carbon isotopes, REE, palaeogeography.

\section{INTRODUCTION}

The understanding of Triassic climatic regimes has been significantly refined by knowledge gained over the past decade (e.g., Berra et al., 2010; Bonis et al., 2010; Preto et al., 2010). Climate change at the end of the Triassic period is usually ascribed to Pangea break-up associated with formation of the Atlantic oceanic rift when Central Atlantic Magmatic Province (CAMP) volcanoes released large amounts of $\mathrm{CO}_{2}$ and/or methane (Beerling and Royer, 2002; Prochnow et al., 2006; Berner and Beerling, 2007; Cohen and Coe, 2007; Hori et al., 2007;

\footnotetext{
* Corresponding author, e-mail: geolmich@savba.sk
}

Received: July 1, 2013; accepted: September 19, 2013; first published online: October 23, 2013
Bonis et al., 2010; Preto et al., 2010) into the atmosphere. Biotic extinction at the end of the Triassic (McRoberts, 1994; McRoberts et al., 1997; Pálfy et al., 2001; Hautmann, 2004; Ward et al., 2004, 2007; Huynh and Poulsen, 2005; McElwain and Punyasena, 2007) was probably caused by this climate change.

Appreciation of the region dispersion of Upper Triassic CAMP volcanic products from a nearly rift in a passive shelf is constrained by the composition of continental deposits along the northern edge of the Tethyan shelf (Blackburn et al., 2013). Temperature, precipitation, and the dynamics of the atmosphere, and also the intensity of weathering processes at the Earth's surface were affected by fluctuations in $\mathrm{CO}_{2}$ concentration (Hesselbo et al., 2002; Ruhl et al., 2010, 2011). Clay-rich sequences with a high kaolinite content in southern Sweden and Poland document the formation of extensive Upper Triassic/Lower Jurassic weathering profiles and palaeosols on granitoids (Kraus, 1989; Ahlberg et al., 2003; Środoń et al., 2006). Rhaetian to Lower Jurassic continental and paralic 
coal-bearing sequences in Spitsbergen (Nagy et al., 2011), Greenland (McElwain et al., 2007, 2009), Denmark (Lund, 1977) and the Hungarian Mecsek Mountains (Ruckwied et al., 2008; Götz et al., 2011) indicate climate humidity. Warming during the $\mathrm{T} / \mathrm{J}$ boundary interval and associated increase in atmospheric carbon dioxide levels favoured a dominance of broad leafved plants that were burned by numerous storm-triggered fires (Belcher et al., 2010).

The Tomanová Formation, which filled a continental basin in the West Carpathian Tatric Zone, has been studied with respect to palaeoflora, palaeoichnology and sedimentology (Raciborski, 1890; Radwański, 1968; Michalík, 2003; Michalik et al., 1976, 1988; Niedźwiedzki, 2011). The presence of kaolinite and smectite reflects the weathering regime in a particular sedimentary basin, and allows its correlation with patterns in neighbouring areas (Weaver, 1989; Ahlberg et al., 2003; Ruffell et al., 2002; Środoń et al., 2006; Dera et al., 2009; Zajzon et al., 2012).

The intensity of weathering, the composition of the parent rocks and the sediment provenance of the material can be indicated by means of chemical analysis, particularly by ratios of major elements and by trace element distribution (Murray et al., 1992; Cullers, 2000; Price and Velbel, 2003; Mongelli et al., 2006; Prochnow et al., 2006; Ohta and Arai, 2007; Sheldon and Tabor, 2009; Galbarczyk-Gąsiorowska, 2010). The specific distribution of REE known from terrestrial deposits and palaeosols may act as an another indicator of climate as well as of sedimentary conditions (e.g., Nesbit et al., 1990; Condie,1993; Hannigan and Sholkovitz, 2001; Haley et al., 2004; Shields and Webb, 2004; Ounis et al., 2008).

The stratigraphic patterns of carbon isotope in organic matter may be compared with ichnological and palynological data (Kuerschner et al., 2007; Ruckwied et al., 2008; Ruckwied and Götz, 2009; Michalik et al., 2010, Götz et al., 2011; Sha et al., 2011) and with the geochemistry of terrestrial shale. Carbon isotope analysis is a generally accepted indicator of chages in the global carbon cycle especially in marine sequences (e.g., McRoberts, 1994; Pálfy et al., 2001; Ward et al., 2004, 2007). Carbon isotope patterns are also present in continental sediments but are significantly less expressive (Hesselbo et al., 2002; Lucas and Tanner, 2007).

The most complete $\mathrm{T} / \mathrm{J}$ boundary sequences in the Central Western Carpathians are preserved in the Fatric Zliechov Basin (Michalik, 2007; Michalik et al., 2007, 2010, 2013). Besides biostratigraphy and C-isotope stratigraphy, clay mineralogy is also considered as a useful tool for evaluation of climatic and weathering conditions. Quantitative analysis of clay fractions resulted in the finding of sharp increases in kaolinite content in marine shales of the Hettangian Kopieniec Formation (Michalik et al., 2010).

This paper aims to integrate sedimentological, mineralogical and geochemical studies of a terrestrial sequence in the Červený Úplaz section of the Tatra Mts. and to summarize Late Triassic palaeoclimatic data. Although the Tatric sequence contains sedimentary gaps and the record of the Triassic-Jurassic transition was apparently affected by a transgression, detailed documentation of the kaolinite weathering crust provides valuable palaeoclimatic information. Another aim of this work is to present new data on the distribution of organic carbon and on the isotopic composition of organic matter in these continental deposits in terms of indications of disturbances of the carbon cycle during climate change. The source of the material that accumulated in the sequence studied may be constrained by the distribution of major and trace elements, including rare earth elements. Finally, we discuss the palaeogeographic position not only of the Tomanová Formation within Tatric sequences in the
Central Western Carpathians, but also within a wider Tethyan framework.

\section{MATERIALS AND METHODS}

\section{SAMPLE PREPARATION}

Sixty four rock samples were collected (Figs. 1 and 2) from the Červený Úplaz ravine section in the Tichá Dolina Valley. Sampling (31 samples) in 2008 concentrated on the Tomanová Fm. argillites. An additional thirteen samples (including thin sections) were collected by M. Sýkora in 1975 from the Tomanová Fm. sandstones have been involved. Later, in 2011, a complementary set of twenty samples was taken from overlying sandy and detrital limestone sequence of the Dudziniec Fm.

Thin sections were examined by transmitted light microscope. Measurements of quartz grain size and quantity were made by means of the NIS-Elements system of screen analysis.

Samples for mineralogical and geochemical analysis were milled to than $0.16 \mathrm{~mm}$; homogenised and equivalent parts of samples were used to analyse mineral and chemical compositions (Fig. 2).
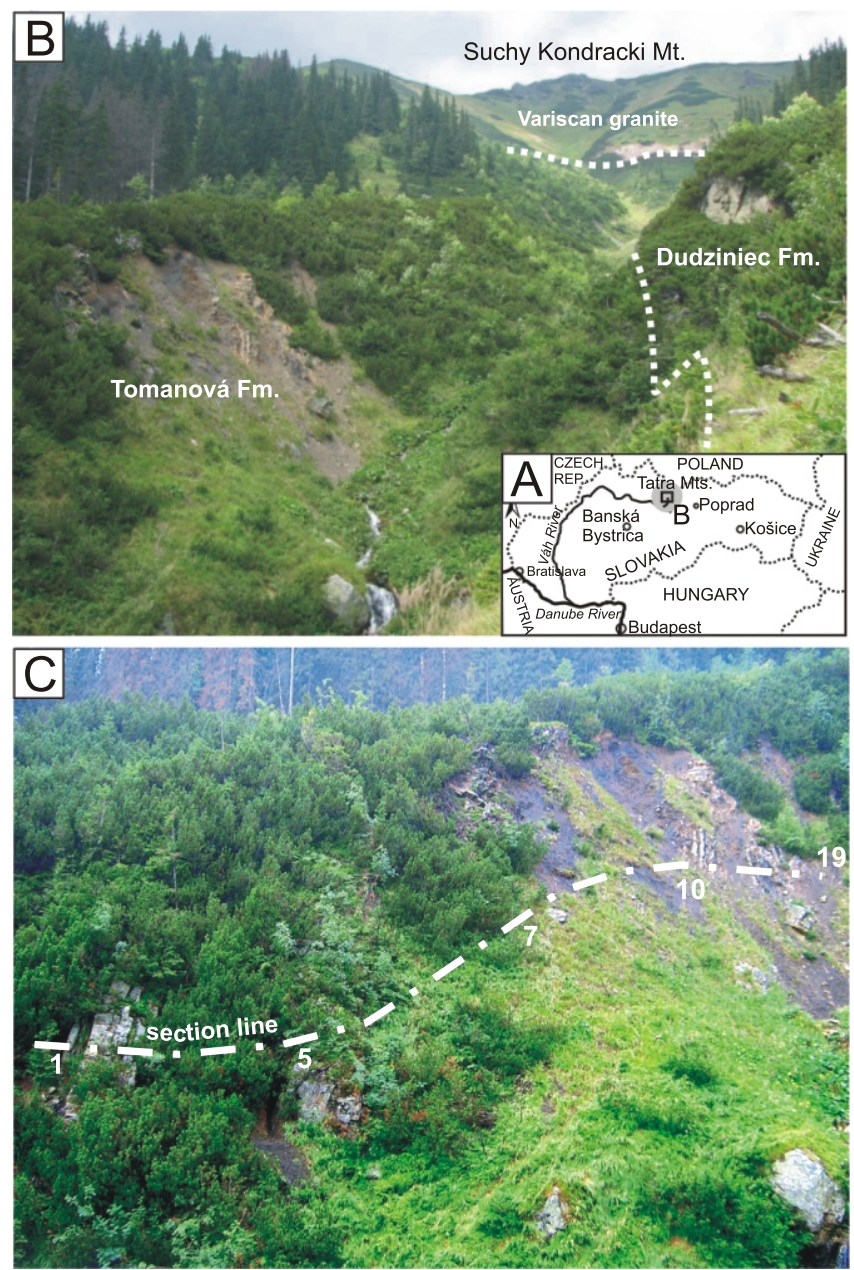

Fig. 1A - location of the Červený Úplaz section in Slovakia, B - investigated area, $\mathrm{C}$ - the section documented on Figure 4

\section{$1,5,7,10,19$ - number of the beds}


ČERVENÝ ÚPLAZ

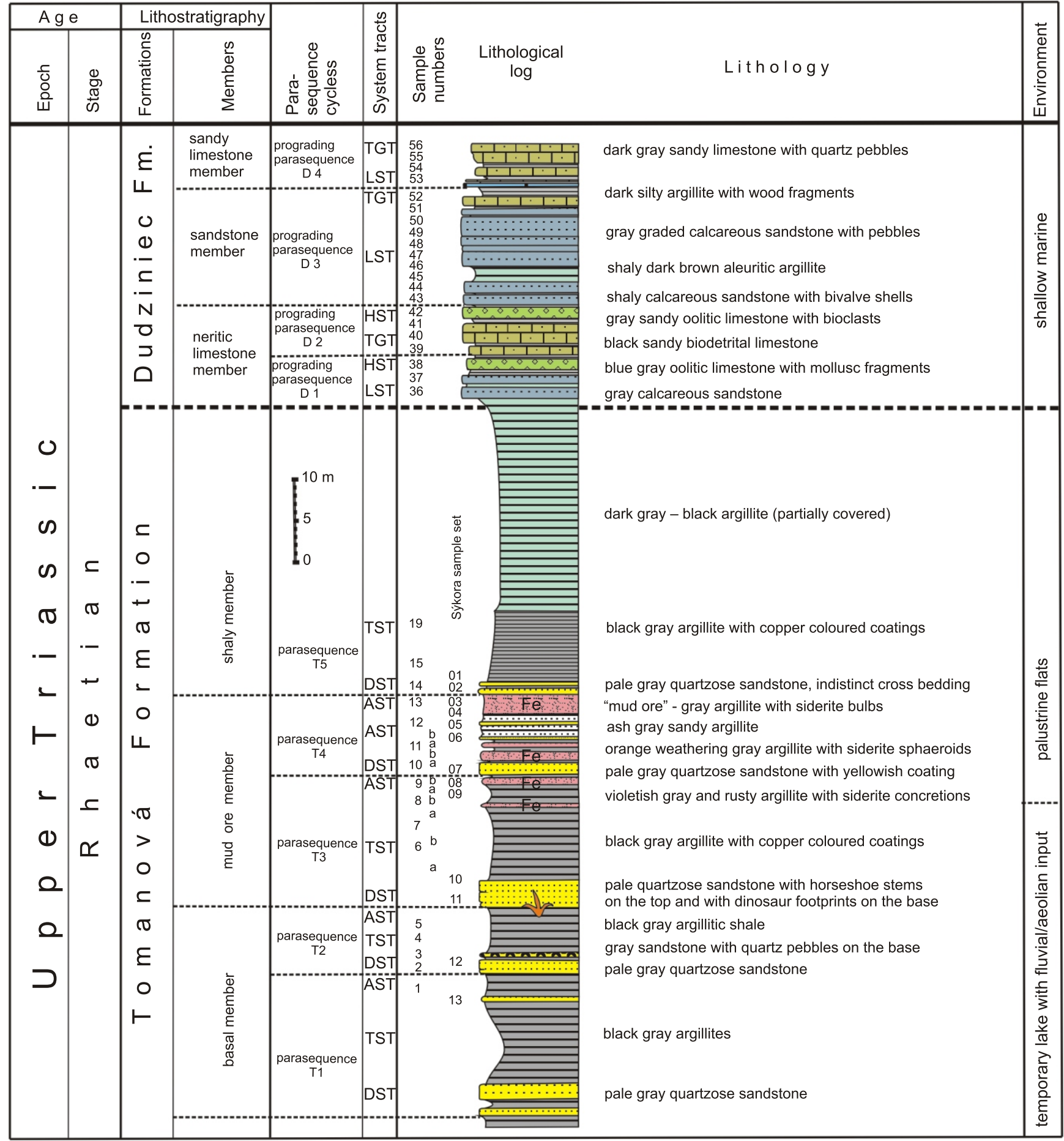

Fig. 2. Stratigraphic, lithostratigraphic division and sequence stratigraphic division of the Červený Úplaz section A

AST - aggradational systems tract, DST - degradational systems tract, HST - highstand systems tract, LST - lowstand systems trac, TGS transgressive systems tractt, TST - transitional systems tract; sample numbers (both for thin sections and for chemical analyses) left column

- "new" sample set, right - a sample set kindly supplied by Dr. M. Sýkora 
MINERALOGICAL ANALYSIS

The mineral composition of clastic and carbonate enriched sedimentary rocks was analysed using X-ray diffraction techniques. Both, clay and bulk rock fractions were studied. The identification of clay minerals in the less than $2 \mu \mathrm{m}$ (clay) was performed in 25 samples. The modified Jackson treatment of Šucha et al. (1991) was applied to $10 \mathrm{~g}$ of milled and homogenized sample. Samples were ultrasonically disintegrated in distilled water and then chemically treated to eliminate carbonates, free iron oxides and organic matter separated by gravity settling in cylinders and by centrifugation respectively. The clay fraction was saturated with sodium ions. Finally, the suspension was poured into semi-permeable tubing and all chloride ions were removed by dialyses in redistilled water. The glass slide method was used to prepare oriented specimens (Moore and Reynolds, 1997). Two X-ray diffraction patterns of each sample were made in Na-saturated air-dried and ethylene glycol (EG - overnight vaporised at $60^{\circ} \mathrm{C}$ ) forms in order to identify possible expandable clay minerals. X-ray diffraction analyses were performed on a Phillips PW1710 diffractometer using CuK $\alpha$ radiation (40K, 20 $\mathrm{mA}$ ) and a diffracted beam graphite monochromator. Samples were scanned from $2-50^{\circ} 2 \Theta$ with a step size of $0.02^{\circ} 2 \Theta$ and using a 1 seconds counting time.

Quantitative mineral analysis of the clay fraction was performed on five selected samples and on 29 bulk rock samples. Three grams of each sample were mixed with 0.333 grams of the internal standard zincite $(\mathrm{ZnO})$ and with $4 \mathrm{ml}$ of denatured alcohol. The mixture was milled for 5 minutes in a McCrone Micronizing Mill to diminish grain size less to than $20 \mu \mathrm{m}$ and to eliminate preferential orientation of crystals in the sample. Each specimen was dried and a side-loaded sample technique was used (Środoń et al., 2001). X-ray diffraction analyses were performed on a Phillips PW1710 diffractometer. Samples were scanned from $4-65^{\circ} 2 \Theta$ with a step size of $0.02^{\circ} 2 \Theta$ and using two a second counting time. The percentages of minerals were estimated from the XRD pattern using RockJock software. Measurement error in the kaolinite and quartz mixture was calculated to $\pm 4 \%$. The errors for minerals in many samples could be larger than $\pm 4 \%$, as minerals in the samples were not identical with the minerals used as standards (Eberl, 2003).

\section{TOTAL CARBON ANALYSIS}

The contents of total organic carbon (TOC) and total inorganic carbon (TIC) were detected in 35 rock samples on a C-MAT 5500 device of the Ströhlein firm in the Geological Institute Laboratory of the Slovak Academy of Science in Banská Bystrica. The TIC content was re-calculated on the content of $\mathrm{CaCO}_{3}$

\section{ISOTOPE ANALYSIS}

Eleven limestone samples and four samples with siderite were selected for stable $\mathrm{C}$ and $\mathrm{O}$ isotope analysis of the carbonate minerals. The isotope ratio of oxygen and carbon was analysed in $\mathrm{CO}_{2}$ after standard decay of samples in $100 \%$ phosphoric acid. The analyses were made in laboratories of both the Czech Geological Institute in Prague on a Finigan MAT-2 mass spectrometer, and at the Geological Institute of the Slovak Academy of Science in Banská Bystrica on a Mass Spectrometer MAT253 equipped with the Gasbench device (Thermo Scientific Samples) of carbonate finely ground to ca. $2 \mu \mathrm{m}$. The results are given in standard del - notation $(\delta)$ in promille $(\%)$ being related to the Vienna International Isotopic Standard (VPDB) with $0.01 \%$ accuracy.

The carbon isotope ratio of organic carbon was analysed in 30 samples. Total organic carbon isotope analysis was carried out after carbonate dissolution. Samples were boiled in dilute $(10 \%)$ hydrochloric acid, then repeatedly rinsed with de-ionized water to remove chlorides and dried at $60^{\circ} \mathrm{C}$. Measurements of $\delta^{13} \mathrm{C}$ were performed by flash combustion in a Fisons $1108 \mathrm{Ele}-$ mental Analyser coupled with a Mat 251 isotope ratio mass spectrometer in a continuous flow regime. The sample size was adjusted to contain a sufficient amount of organic carbon to obtain external reproducibility of $0.15 \%$ for $\delta^{13} C_{\text {org }}$ for all types of samples with NBS 22 as the reference material. Isotope data are reported in the usual delta $(\delta)$ notation relative to the VPDB (Laboratory of the Czech Geological Survey in Prague).

TOTAL ROCK CHEMICAL ANALYSIS

In this study, fourteen samples were analysed geochemically using a Perkin Elmer Elan 6000 ICP at the ACME Analytical Laboratories, Ltd in Vancouver, Canada. Total abundances of the major oxides and several minor elements $\left(\mathrm{SiO}_{2}, \mathrm{Al}_{2} \mathrm{O}_{3}, \mathrm{Fe}_{2} \mathrm{O}_{3}\right.$, $\mathrm{CaO}, \mathrm{MgO}, \mathrm{Na}_{2} \mathrm{O}, \mathrm{K} 2 \mathrm{O}, \mathrm{MnO}, \mathrm{TiO}_{2}, \mathrm{P}_{2} \mathrm{O}_{5}$ ) are reported on a $0.2 \mathrm{~g}$ sample analysed by ICP-emission spectrometry following a lithium metaborate/tetraborate fusion and dilute nitric digestion. Loss on ignition (LOI) is by weight difference after ignition at $1000^{\circ} \mathrm{C}$. Both trace elements (Ba, Co, Cs, Ni, Rb, Sc, Sr, Th, V, Y, Zr) and Rare Earth Elements (REE) were determined by ICP mass spectrometry following a lithium metaborate/tetraborate fusion and nitric acid digestion of $0.2 \mathrm{~g}$ samples. In addition, a separate $0.5 \mathrm{~g}$ split was digested in Aqua Regia and analysed by ICP mass spectrometry for precious and base metals (the ACME Analytical Laboratories, Ltd., 2008).

Samples for chemical analysis were selected according to stratigraphic position (nine shale + four carbonate samples) and according to the mineral composition determined. Data were compared to Post Archaean Australian Shale (PAAS) chemical composition (Taylor and McLennan, 1985). Inter-elemental relationships were evaluated using the Pearson's Correlation Factor. The chemical Index of Weathering $\mathrm{CIW}=\left[\mathrm{Al}_{2} \mathrm{O}_{3}\right]$ $\left.\mathrm{Al}_{2} \mathrm{O}_{3}+\mathrm{Na}_{2} \mathrm{O}\right]^{*} 100$ ) was used to compare the intensity of weathering of the shales studied (see e.g., Ohta and Arai, 2007, Sheldon and Tabor, 2009). The chemical Index of Alteration (CIA = $\left[\mathrm{Al}_{2} \mathrm{O}_{3} / \mathrm{Al}_{2} \mathrm{O}_{3}+\mathrm{CaO}+\mathrm{Na}_{2} \mathrm{O}+\mathrm{K}_{2} \mathrm{O}\right] \times 100$ ) was used to document sediment alteration (Nesbit and Young, 1984; Price and Velbel, 2003). $\mathrm{K}_{2} \mathrm{O}$ vs. $\mathrm{TiO}_{2}$ and $\mathrm{Al}$ vs. Ti as ratios of major labile and stable elements in the weathering process were calculated to check the influence of transport and recycling. Indices were calculated using molecular proportions of the major element oxides in elementary expression. The chemical character of parent rock was tested on the basis of trace elements. Contents in ppm were used in indices. REE were normalized to chondrite and to PAAS (Taylor and McLennan, 1985). The Eu/Eu* ratio (values of Eu anomaly) was calculated using $\mathrm{Eu} / \mathrm{Eu}^{*}=\mathrm{Eu}_{\mathrm{PAAS}} /\left(\mathrm{Sm}_{\mathrm{PAAS}} \times\right.$ $\left.\mathrm{Gd}_{\text {PAAS }}\right)^{0.5}$ or $\mathrm{Ce} / \mathrm{Ce}^{*}=\mathrm{Ce}$ PAAS $/\left(\text { LapAAS } \times \mathrm{Pr}_{\text {PAAS }}\right)^{0.5}($ values of $\mathrm{Ce}$ anomaly), respectively.

\section{GEOLOGICAL SETTING}

The Tatra Mts. are situated at the margin of the Central Carpathians. This mountain system consists of imbricated nappe units. The deepest (Tatric) part of the High Tatra Mts. is formed by a Variscan crystalline block with large granitoid bodies covered by Lower Triassic-middle Cretaceous strata (Uhlig, 
1897; Dumont et al., 1996). This basement is overlain by a superficial nappe complex consisting of the lower (Fatric) Krížna Nappe and of the upper (Hronic) Choč Nappe (Andrusov et al., 1973; Kotański, 1979). During the Triassic, the Central Western Carpathian units belonged to the northern Tethyan shelf formed of Variscan consolidated crust (Kozur 1991; Michalík, 1993, 1994, 2003; Michalík et al., 2007; Kuerschner et al., 2007).

Raciborski (1890) defined the "Tomanová Beds" as an uppermost Triassic (Rhaetic) complex of variegated clastic deposits (Michalík, 1977, 2003). The Tomanová Formation is underlain by the Carpathian Keuper (Uhlig, 1897; Michalík et al., 1976). Carpathian Keuper strata were deposited in a dry and hot climate on an emergent Middle Triassic carbonate ramp (Al-Juboury and Ďurovič, 1992; Jaglarz and Szulc, 2003; Jaglarz, 2010). A variegated claystone succession of Carpathian Keuper is developed in two facies: a more proximal red-bed facies contains siliciclastic intercalations, while a more distal violet succession is intercalated by dolostone layers indicating short-lived marine ingressions (Michalík, 1994; Rychliński, 2008; Michalík et al., 2013). The Keuper strata are mostly devoid of index fossils and so their age determination is difficult. They are overlain by marine transgressive deposits of the Fatra Formation in the Fatric Zliechov Basin (Michalík, 1977. 2007; Gaździcki, 1974; Gaździcki et al., 1979), and by continental siliciclastic deposits, lacustrine to palustrine black silty shales and quartz sandstones with plant remains in the Tatric Domain (e.g., in the Červený Úplaz section; Michalík et al., 1976, 1988).

Several sections of the Tomanová Formation both in the Slovakian and Polish parts of the Tatra Mts. area have been studied for more than a hundred years (for review see Michalík, 2003; Niedźwiedzki, 2011). Published data indicated that the deposits of the Tomanová Fm. accumulated from the latest Triassic until the earliest Jurassic (Raciborski, 1890; Kotański, 1959, 1961; Radwański, 1968; Michalík et al., 1976, 1988; Fijałkowska and Uchman, 1993). Valuable stratigraphic and ecologic a information on this terrestrial sedimentary sequence has been provided by ichnological study since the first dinosaur traces were discovered in the Tichá Dolina Valley section (Michalík et al., 1976; Niedźwiedzki, 2005). Michalík et al. (1976) described a new ichnospecies Coelurosaurichnus tatricus based on three tridactyl ichnites preserved on a sandstone slab. Niedźwiedzki (2011) concluded that ichnotaxa preserved in the Tomanová Fm. are comparable with several Triassic dinosaur track types and also with Early Jurassic ichnomorphotypes.

Studied section. The Červený Úplaz ravine is exposed in a steep side of the Tichá Dolina Valley in a cut of one of the tributaries of the Tichý Potok Brook approximately $1350 \mathrm{~m}$ above sea level (E 1956'51.36"; N 49'13'35.04", alt. $1340 \mathrm{~m}$ above sea I.) $700 \mathrm{~m}$ below the Slovak-Polish state frontier (Fig. 1).

This section has been studied in detail by several authors dealing with the Tatric Upper Triassic cover sequence (Gorek, 1958; Rabowski, 1959; Kotański, 1961; Radwański, 1968). Dinosaur traces and macro and micro plant remains were collected by Michalík et al. (1976, 1988). Planderová (in Michalík et al., 1976) described two microfloral associations: black claystones in the lower (older) part of the section contain predominantly Taeniasporites, Protohaploxypinus, while the sandstone-shale part in the upper part yields pollen grains of Classopollis and Gliscopollis. This fern flora indicates stabilizing of a wetter climate with a palustrine flora (Michalík et al., 1988). The flora described indicates palaeoecological and palaeoclimatic/palaeogeographic changes associated with transgression gradually affecting the Tatric sedimentary basin.

Uhlig (1897) recognized a continuation of the Tomanová Fm. sedimentation from the Carpathian Keuper deposits, which form underlying beds in other regions (the Czerwone Żlebki, or
Tomaniarski Twardy Upłaz ravines on the Polish side of the mountains). Gorek (1958) suggested that the base of the formation is deeply erosive, resting on Lower Triassic "Campilian" strata in the Tichá Dolina Valley. This view was questioned by Kotański (1961) and Radwański (1968), who noted the tectonic deformation of this Triassic strata slice, overthrust by the Goryczkowa Mt. granitoid body. Michalík et al. (1988) and Michalík (2003) presented the results of a lithological and cyclostratigraphic analysis and proposed a sedimentary model. They recognized several more or less complete sedimentary cycles in about $60 \mathrm{~m}$ of strata (Fig. 2).

The character of the upper boundary of the Tomanová Fm has not been documented in detail. In the section, studied the Tomanová Fm. is followed by quartz sandy limestones and calcareous sandstones (Michalík et al., 1976). Gorek (1958), Rabowski (1959) and Kotański (1961) assumed a Hettangian age, while Radwański (1968) placed it in the upper Rhaetian.

\section{SEDIMENTOLOGY}

\section{LITHOLOGY OF THE ČERVENÝ ÚPLAZ RAVINE SECTION}

The Tomanová Formation is a sequence of fine-grained clastic rocks - siliceous pelites, sillstones and medium-grained sandstones (Figs. 2 and $3 \mathrm{~A}, \mathrm{~B}$ ). The architecture of the approximately $80 \mathrm{~m}$ thick sequence is arranged in five more-or-less regular prograding and fining-upwards parasequence cycles (Michalík, 2003; Fig. 2). Although frequent synsedimentary erosion and gaps occur in the sequence (four of the cycles are merged into couplets), a typical complete cycle attains a thickness of $830 \mathrm{~cm}$.

Each cycle starts with a light coloured sandstone bed with an erosive base, locally with Rhizocorallium traces. Quartz sandstone (with $55-75 \%$ of quartz; Fig. 4) with a quartzose silty-clayey matrix with Fe-oxide admixture is grading to laminated clayey sandstone and silty claystone (Figs. 3A, B and 5G, H). Michalík et al. (1988) noted that monocrystalline grains from plutonic rocks prevailed in the lower part of the sequence while higher up individual polycrystalline grains were most probably derived from metamorphic rocks. Some quartz grains are penetrated by numerous parallel fissures.

A substantial part of the Tomanová Formation is formed by dark mudstones of fluviatile origin with a significant content of aeolian tiny $(<0.2 \mathrm{~mm})$ angular quartz grains (Figs. 4 and $5 \mathrm{~A}, \mathrm{~B})$. The major part of the section is formed by thick shaly beds. Detrital quartz grain size decreases from $3 \mathrm{~mm}$ in the sandstones to $1 \mathrm{~mm}$ in the graded part and to less than $0.2 \mathrm{~mm}$ in silty mudstones .

Claystones consist of mica, quartz kaolinite and organic matter (mostly plant fragments studied by Michalík et al., 1988; Figs. 4 and $5 C, D$ ). The autochthonous palustrine flora is represented by horsetails; other remnants were more or less transported. Coal occurred as laminae or thin intercalations though only negative imprints of fossil wood were found at this locality (Fig. 3C). Early fusinisation of many fragments indicates local forest fires similarly as described by Belcher et al. (2010) or Petersen and Lindström (2012).

Accumulations of concentric ferruginous nodules (up to 25 $\mathrm{cm}$ in diameter; Fig. 3D) form recognizable levels in completely developed cycles, being more expressive in the upper part of the sequence (Figs. 3C and 4). They are composed of tiny globular siderite bodies (0.7-2 mm across; Fig. $5 \mathrm{~B}$ ) in a clayey matrix. Gorek (1958) regarded them as spherical heavily oxidized pyrite concentrations which provide the name of the Červený Úplaz lo- 

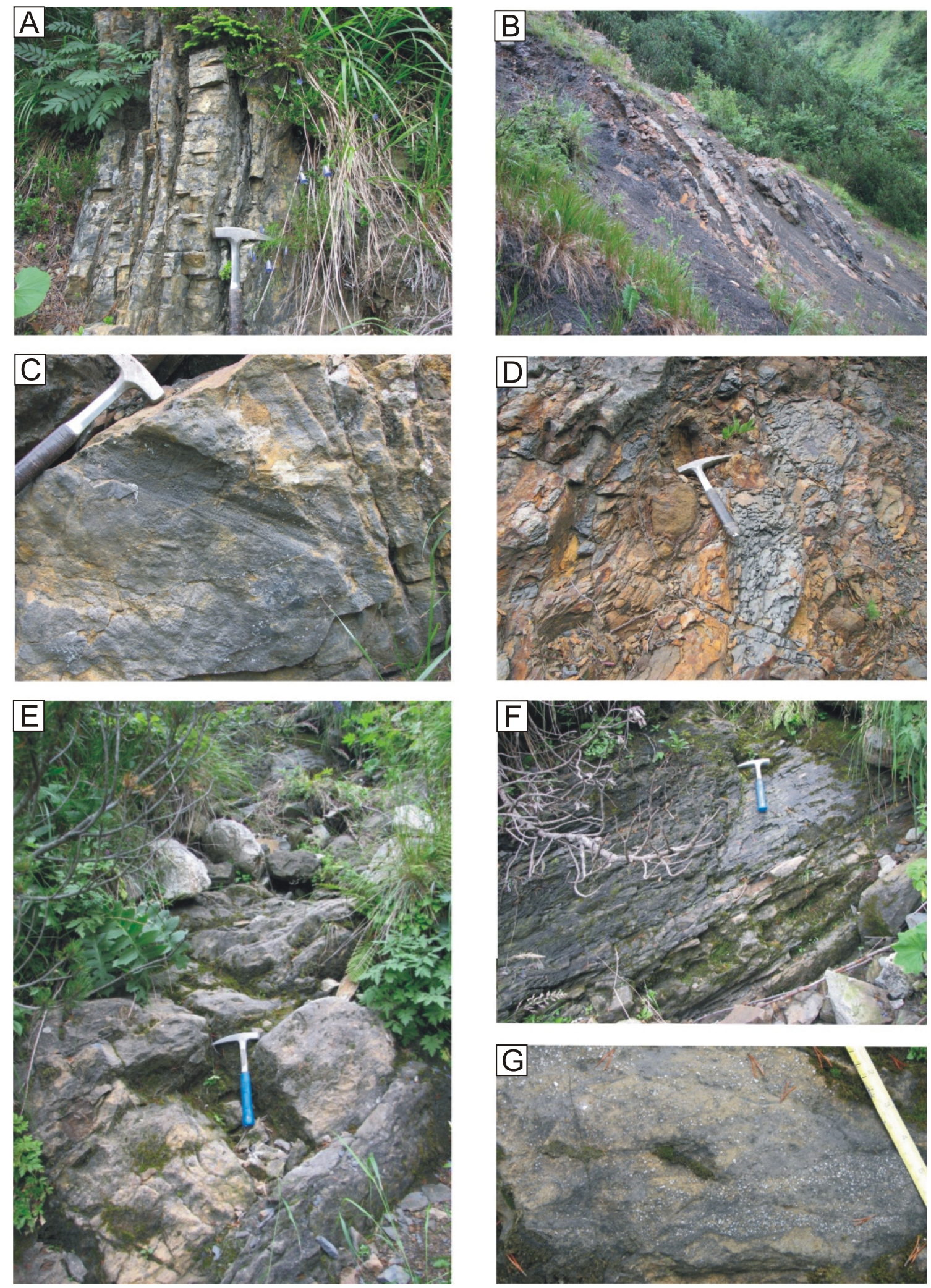

Fig. 3. Field photos of typical macrofacies

A - thin-bedded sandstones and mudstone (beds 02-03); B - sandstone/silty mudstone/sideritic mudstones (beds 10-19); C - upper surface of sandstone bed 05 with imprints of numerous horsetail stems; D - silty mudstone with sphaeroidal concretions of siderite (bed 13); E sandy limestone to calcareous sandstone with silty mudstone interbeds (beds 40-46); F - aleurolitic shale; G - sandy limestone with bands of fluviatile quartz grains (bed 53); length of hammer $31 \mathrm{~cm}$ 


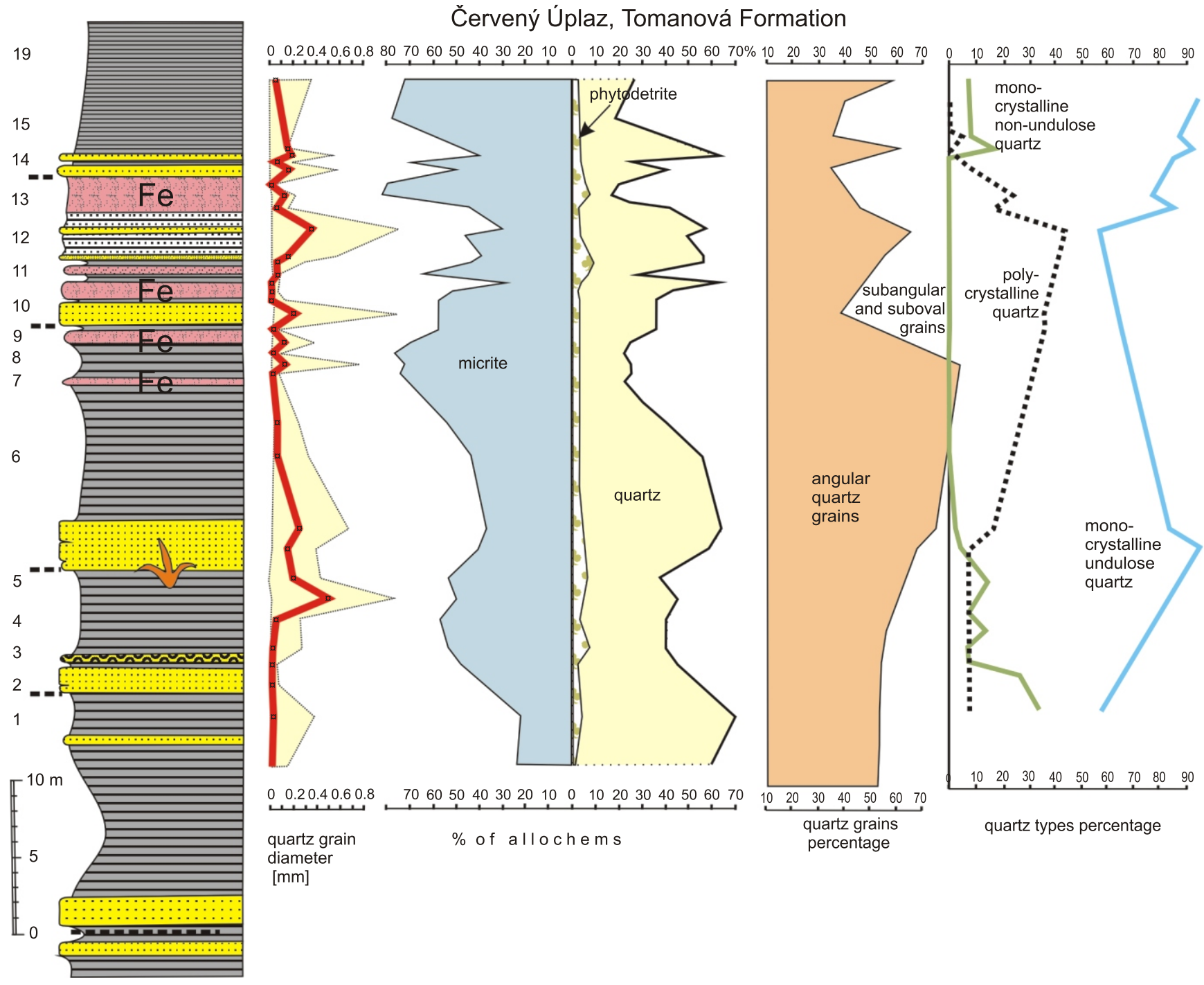

Fig. 4. Lithostratigraphy of the Tomanová Formation, the Červený Úplaz section in the Tichá Dolina Valley, High Tatra Mts.

Left - schematic sequence stratigraphic division; in the lithological log, iron-rich mudstone horizons (Fe), dinosaur footprint (tridactyl) horizons and conglomeratic beds (circles) are indicated; in the distribution of quartz grain diameter the minimum (left line), median (thick line) and maximum diameter (right line) are marked; in the column of rock constituents, the amount of micrite (mostly clay minerals) increases to the left, the amount of quartz and phytoclasts increases to the right; the right two columns indicate changes in the angularity of clasts and the content of polycrystalline and monocrystalline undulous/non-undulous quartz grains; other explanations as in Figure 2

cality ("Red Glen”). However, Radwański (1968) questioned this opinion and stressed their carbonate composition. He compared them with pisoliths in the Czerwone Żlebki locality where their erosion and redeposition preceded the limonitization process. The content of quartz grains in sideritic layers is low (18-22\%), and their small grain size (0.01 to $0.2 \mathrm{~mm}$; Figs. 4 and $5 \mathrm{~B})$ suggests an aeolian origin. This sequence is covered by scree and brook alluvial deposits

The Dudziniec Formation was defined by Lefeld et al. (1985). The sequence exposed in the Červený Úplaz section (32 m) consists of five informal members (Fig. 2) composed of prograding parasequences. Each parasequence shows a trend parallel with terrestrial cycles of the Tomanová Fm., from fluvially derived sandstone through calcareous rock influenced by aeolian dust, to fully marine limestone. Radwański (1968) mentioned lydite fragments, zircon, tourmaline, and rutile grains which occur sporadically in a low diversity spectrum of heavy minerals.
The lower member comprises two parasequences (resembling the "Kopieniec Starorobociański Bed" of Lefeld et al., 1985) and is built of grey calcareous sandstone followed by shaly argillites, sandy oolitic and organodetrital limestone with fragments of coral determined by Prof. E. Roniewicz (2010, pers. comm.) as Phacelostylophyllum cf. robustum, bivalves, crinoids and gastropods. Angular quartz grains of aeolian size $(0.1-0.24 \mathrm{~mm})$ are formed of monocrystalline undulose (rarely non-undulate) quartz (Figs. 6G, $\mathrm{H}$ and 7 ).

The middle member is formed of calcareous sandstones. They comprise graded beds, quartz grains in the basal parts of the layers attaining diameters of 1 to $5 \mathrm{~mm}$; they are subangular, partly arranged in laminae. Subangular to suboval grains formed of polycrystalline quartz (Figs. 6E and 7).

The upper member is more clayey, of dark gray silty mudstones including wood fragments and quartz pebbles. Frequent dark coloured (brown weathering) sandy biomicrite limestone layers are also rich in pellets, small pebbles and monocrystalline quartz grains (Figs. 6A-D, F and 7). 

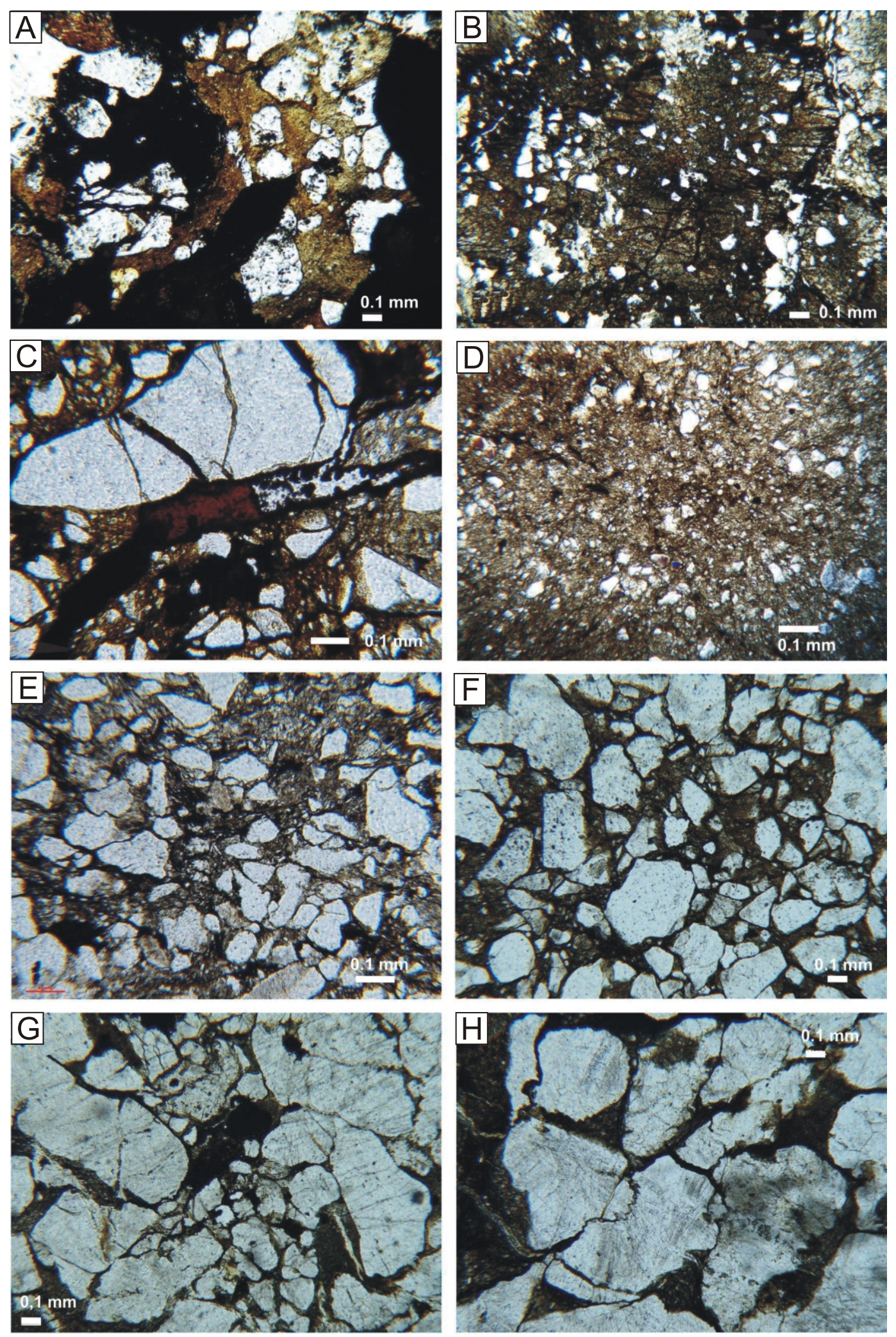

Fig. 5. Microfacies of the Tomanová Formation in the Červený Úplaz section

A, B - iron-rich mudstone beds (A - S-8 bed, B - S-4 bed with siderite aggregates and with abundant aeolian quartz grains); C - (04-c) beds with fragments of wood and indeterminable plant debris; $\mathbf{D}-($ (13-b) mudstone with aeolian quartz sand grains; $\mathbf{E}$ - (01-b) sandstone with mixed aeolian and fluvial quartz sand grains; $\mathbf{F}-(\mathrm{S}-6)$ sandstone with common large (fluviatile) sand quartz grains; G, H - (07 and 05) quartz grains of fluvial origin; note dense parallel fractures in individual grains 

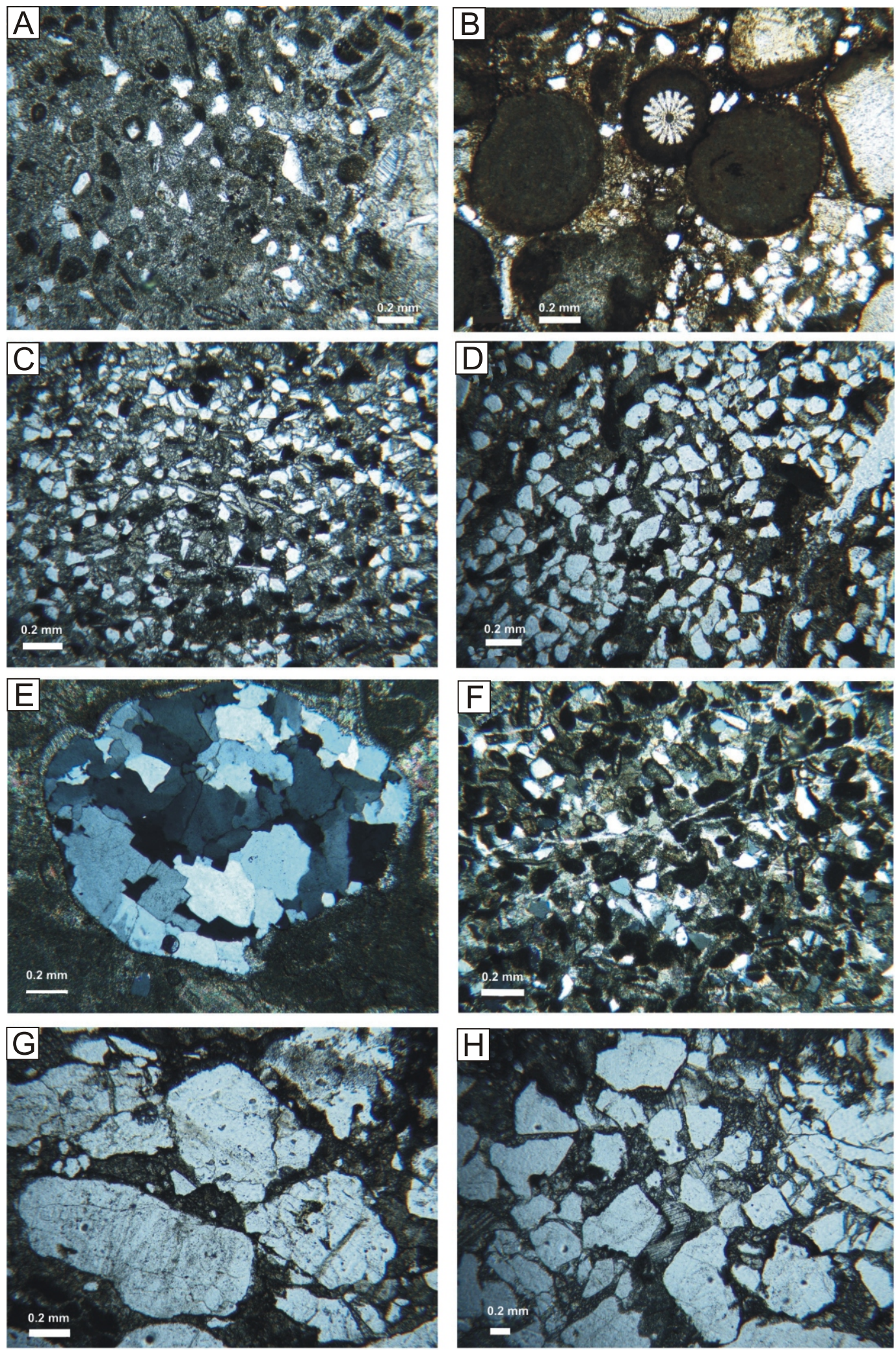

Fig. 6. Microfacies of the Dudziniec Formation in the Červený Úplaz section

A - (40 bed) biodetrital shelly limestone; B - (42 bed) sandy oolitic limestone, fluviatile sandstone (beds $01 \mathrm{~b}$ and 04c, respectively); C, D - (55 and 41,1 beds, respectively) laminae of fluvial quartz grains in mudstone with strong aeolian quartz admixture; E - (38.5 bed, crossed nicols) large polycrystalline well-rounded quartz grain; F - (38.5 bed, crossed nicols) biomicritic silty limestone with aeolian quartz; G - (46 bed) sandstone composed of fluvial monocrystalline quartz grains; $\mathbf{H}$ - (36 bed) sandstone with fluviatile quartz grains dominant over aeolian grains 


\section{Červený Úplaz, Dudziniec Formation}

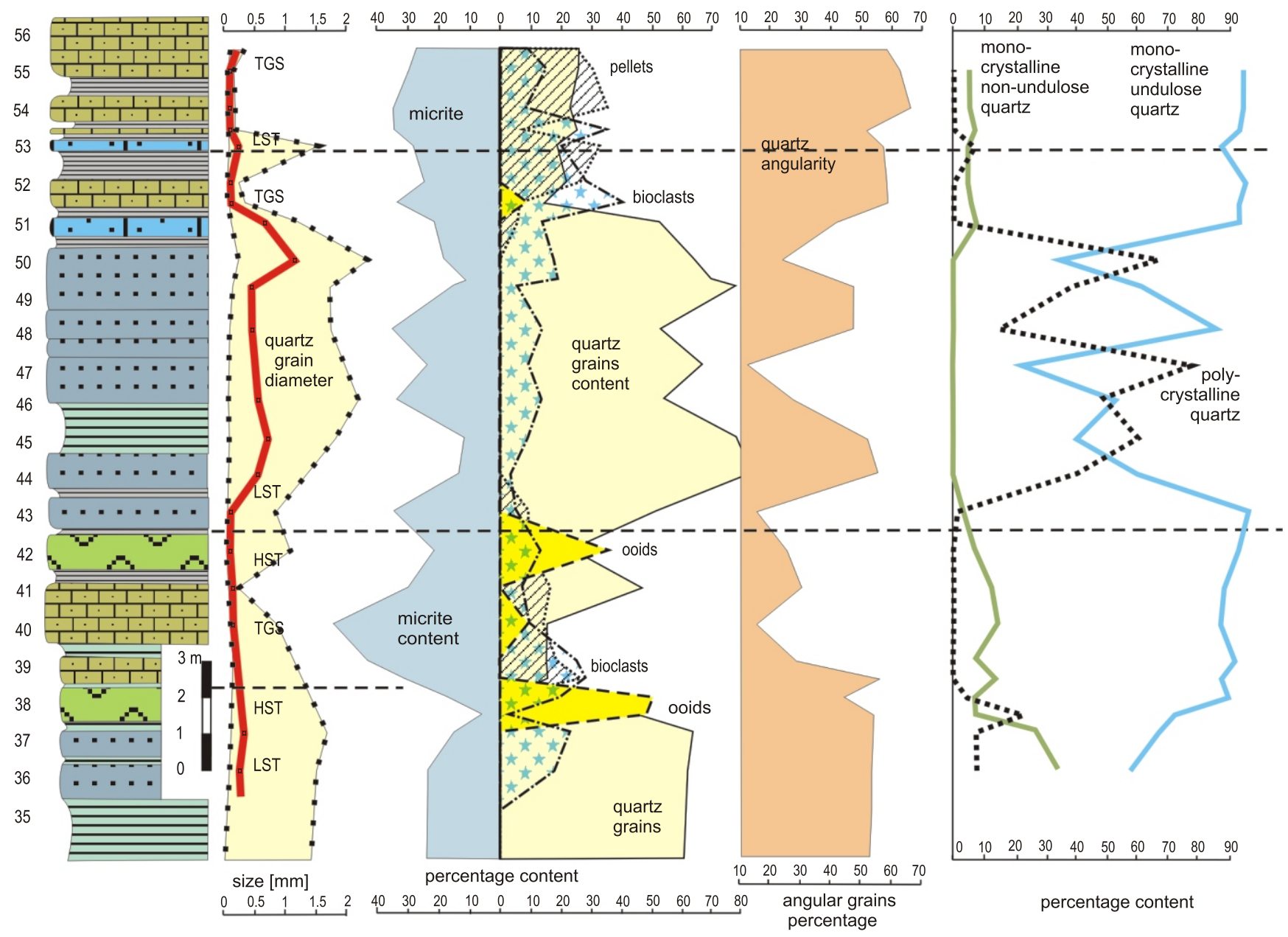

Fig. 7. Lithostratigraphic scheme of the Dudziniec Formation in the Červený Úplaz section

Left - schematic sequence stratigraphic division (explanations as in Fig. 2); in the lithological log distribution of quartz grain diameter the minimum (left line), median (thick line) and maximum diameter (right line) are marked; in the column of rock constituents, the amount of micrite (mostly clay minerals) increases to the left, the amount of quartz, pellets and bioclasts to the right; the right two columns indicate changes in the angularity of clasts and in contents of polycrystalline and monocrystalline undulose non-undulose quartz grains

\section{REMARKS RECORDING CYCLOSTRATIGRAPHIC INTERPRETATION}

The cyclical variation of rock composition and the stratal architecture of the uppermost Triassic sequences were driven by orbital forcing of climate and/or ocean circulation (Blackburn et al., 2013). The character of the deposits building the Tomanová Formation cycles indicates that their deposition was controlled by mega-monsoonal climate variations (massive freshwater supply during periodic pluvial events) rather than by eustatic fluctuations of the water table.

The sandstone layers represent a record of fluvial episodes during degradation phases of sedimentary cycles (Fig. 4). The dynamics of their accumulation may be documented by dinosaur track casts (the footprints were made on the surface of siltstone layers and immediately filled and covered by fluvial sand), or by discontinuous pebble horizons on the bases of sandstone benches, as well as by many fragments of horsetail stems concentrated on the upper surfaces of sandstone layers (Fig. 3C).
As the sandy material accumulated during brief events, a proxy of elapsed time is recorded by mudstone between the sandstone layers. They were laid down in a calm lacustrine (paludal) with input of both fine fluvial mud and aeolian dust. Overall the sedimentation rate of the Tomanová Formation may have attained $83 \mathrm{~mm} / \mathrm{ky}$. If cycles are attributed to orbital short eccentricity, the section documented would represent a time period of about $0.78 \mathrm{My}$.

As already stated, the trend from fluvial-dominated to fine-grained sediments is common both in terrestrial and marine cycles. This reflects a persistent principal character of the climate during sedimentation of the Tomanová and Dudziniec formations. The sedimentary rate of the Dudziniec Formation has been estimated as $25 \mathrm{~mm} / \mathrm{ky}$. If we assume a short eccentricity character of these cycles, the exposed part of the sequence represents a time span of $0.5 \mathrm{My}$. 
TRANSGRESSIVE MARINE LITHOFACIES AND RECOVERY OF BENTHIC LIFE

The transgressive sequence of the Dudziniec Formation reveals gradual stabilization of the marine environment and recovery of benthic life. This trend may be inferred from the stratigraphic distribution and environmental significance of the benthic foraminifera present.

The Červený Úplaz section can be divided to three benthic foraminifer assemblage zones: a lower one with predominance of involutinids and spirillinids; a middle one with predominance od endothyrinids; and an upper one with predominance of nodosariids and Ammodiscus-type microfauna (Fig. 8A-J). The lower assemblage zone (beds 36-39) contain species of Semiinvolutina clari Kristan, Trocholina blaui SenowbariDaryan, Rashidi and Torabi, Trocholina umbo Frentzen, Aulotortus? sp., Spirillina oberhauseri Styk (Fig. 8A-K) and Ophthalmidium sp. Endothyracean foraminifera dominate in the middle assemblage zone (beds 39-40), comprising species of Endothyra badouxi Zanninetti and Bronnimann, Endothyra keupperi Oberhauser, E. austrotriadica Oberhauser, E. gruenbachensis Oberhauser and Endothyra salaji Gaździcki (Fig. 8D-H). These species likely indicate a Rhaetian age, since the latest occurrence of Endothyra is known from the Late Triassic. The endothyrid foraminifers are associated with Reophax sp., Trochammina alpina Kristan-Tollmann, Agathammina austroalpina Kristan-Tollman and Tollmann, Duotaxis inflata (Kristan), and Siphovalvulina sp. Foraminiferal assemblages in the upper part of the section are enriched in nodosariid and agglutinated species - Ammodiscus parapriscus Ho, Nodosaria simplex (Terquem), Dentalina zlambachensis Kristan, Pseudonodosaria sp., Geinitzinita sp. (Fig. 8A-C).

The transgressive sequence started with sand-rich deposits, which contain a high portion of ooids and other coated grains (initial ooids with microbial rims around quartz grains, Fig. 8K). The mixture of siliciclastic and carbonate particles in a high-energy environment may reflect storm-influenced oolitic shoals. Microbial encrustations and stromatolitic rims on the quartz grains imply increased trophic resources due to riverine input (Fig. 8L, M). The sequence grades up to a fully marine shelf environment (no. 38-39) with foraminifers of the discoidal-flattened and plano-convex morphogroups (Spirillina, Trocholina). These foraminifers belong to a grazing herbivore and detritivore benthic epifauna (Tyszka, 1994; Reolid et al., 2008), which depends on food availability (phytodetritus, bacterial populations) and tolerates oxygen depletion (Tyszka, 2001; Reolid and Martínez-Ruiz, 2012).

The maximum flooding of the transgressive cycle is recorded in intervals of limestone beds (bed 40; Fig. 8), which were deposited in the low-energy environment of a carbonate ramp. These muddy limestones contain skeletal and coated grains, black pebbles, oolitic and peloidal sands, offshore tempestites (gastropod oolites) and a small admixture of siliciclastic material. The stabilization of marine conditions is also recorded by rich benthic foraminifera, which imply an initial colonization of bottom substrates by an epifaunal biota. The most common are Endothyra-type foraminifera, the acme of which occurs in bed 40. Endothyra-bearing limestones represent the recovery interval of a marine environment. Increase in foraminiferal benthic productivity resulted from food availability and bottom-water oxygenation (Tyszka, 1994; Jorrisen et al., 1995; Reolid and Martínez-Ruiz, 2012). The shell morphology of Endothyra with streptospiral coiling may reflect of shallow infaunal habitats (Olóriz et al., 2003), and a feeding strategy of detritivores and bacterial scavengers (Reolid et al., 2008). Considering that, the Endothyra acme in the Červený Úplaz section (bed 40) may have resulted from increase of organic matter productivity and phytodetritus, the decomposition of which provided nutrients (mesotrophic conditions) and led to oxygen depletion of bottom waters (dysoxic conditions).

A new sedimentary cycle started with regression and high-energy deposition of sand-rich sediments (beds 43-50). The sandstones contain rare crinoid particles, echinoid spines, thick-walled bivalves (oysters), ostracods and other skeletal grains. The transgressive phase is expressed by upwards increasing calcareous allochems and a transition to carbonates. The microfauna of the carbonate beds (beds 52-56) contains both agglutinated and calcareous foraminifera, indicating a low-energy environment with nodosariids (cf. Tyszka, 2001), influenced by deltaic assemblages with Ammodiscus (cf. Nagy et al., 2010).

\section{MINERALOGY OF MUDSTONES}

Kaolinite is a major mineral phase in the clay fraction of the shales studied (Fig. 9A). The second most frequently occurring mineral phases in the clay fraction are 2:1 dioctahedral clay minerals (illite and mixed-layered illite-smectite - I-S). Distinctive basal peaks of illite as an unswelling phase without changes appear after ethylene glycol (EG) saturation $(001 \sim 1 \mathrm{~nm}$ and 002 $5 \mathrm{~nm}$ in Fig. 9). On the other hand, small changes in the $8-9^{\circ}$, $17-18^{\circ}$ and $27-28^{\circ} 2$ theta areas after EG saturation reveal the presence of $\mathrm{I}-\mathrm{S}$ with small amounts of swelling smectite interlayers. Long-range ordering R3 with $10-15 \%$ of smectite interlayers was determined by position of the I-S peaks after EG saturation (Dudek and Środoń, 1996; Moore and Reynolds, 1997). 2:1 dioctahedral clay minerals dominate over kaolinite in sample 15 only. The amount of kaolinite is significantly higher than that of 2:1 dioctahedral clay minerals in all other shale samples studied. The presence of a small, broad $\sim 1.4 \mathrm{~nm}$ peak suggests to presence of the small amount of chlorite in practically all samples. A low discrete $0.426 \mathrm{~nm}$ peak indicates an admixture of quartz in all samples (Fig. 9A).

Another clay mineral phase was distinguished simultaneously with kaolinite, illite and I-S in a more significant amount in sample 14. It was the second $0.7 \mathrm{~nm}$ phase $(0.707 \mathrm{~nm})$ after kaolinite $(0.719 \mathrm{~nm}$; Fig. 9B). For distinction of Fe-chlorite (chamosite, that has odd basal peaks including $\sim 1.4 \mathrm{~nm}$ peak), significantly less intense than even basal peaks) and berthierine (1:1 serpentine mineral with $\mathrm{Fe}^{2+}$ dominant as the octahedral cation). The sample was heated to $550^{\circ} \mathrm{C}$. This confirmed the presence of kaolinite and also showed the presence of berthierine (Odin et al., 1988; Hornibrook and Longstaffe, 1996; Moore and Reynolds, 1997). Both phases collapsed after heating (Fig. 9B). A small amount of a chlorite similar phases is also detectable in the Figure 9B. It is not known whether this is chlorite because an unusual low d-spacing was determined for that phase in comparison to common chlorite (1.41-1.42 and $0.7-0.7 \mathrm{~nm}$ )

Five samples of the clay fraction were selected for quantitative analyses. The result of XRD quantitative analyses confirmed the dominance of kaolinite in the clay fraction. The kaolinite content varies from 28 to $61 \mathrm{wt} \%$ (Table 1). The data and relative wide ranges of the main mineral contents confirmed a more varied clay composition in sample 15. Decrease in the kaolinite content (28 wt.\%) is counterbalanced by increase of illite and illite-smectite (46 wt.\%; Table 1). 


\section{Červený Úplaz, Dudziniec Formation}

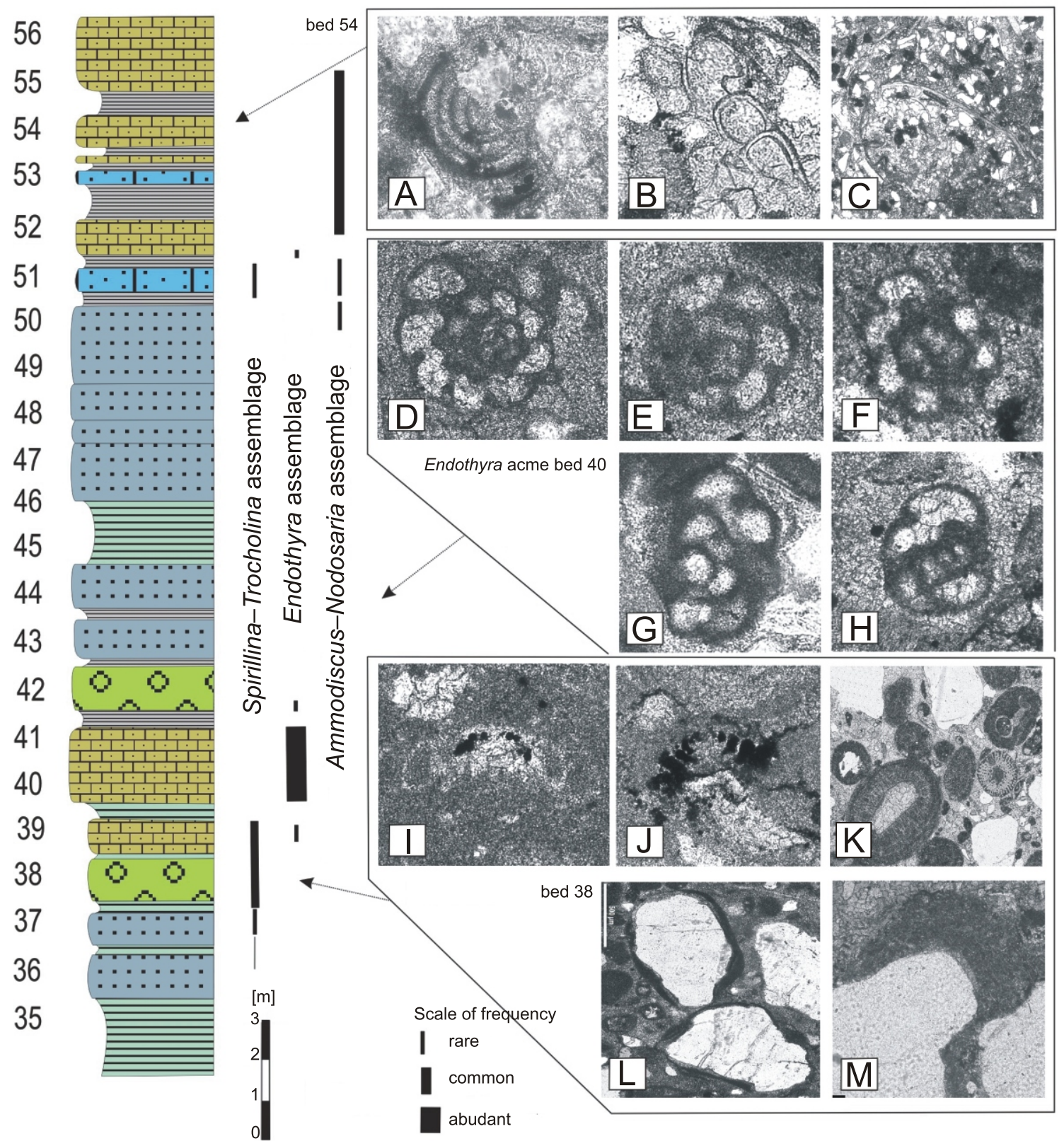

Fig. 8. Distribution of microfaunal elements in the Dudziniec Formation of the Červený Úplaz section

Quantitative data are completed by illustrations of the most characteristic species of foraminiferal assemblages, algal encrusters, coated grains and other allochems in selected beds; A - Ammodiscus parapriscus Ho; B - Nodosaria simplex (Terquem); C - wackestone with thin-walled ostracod shells; D - Endothyra badouxi Zanninetti et Bronnimann; E Endothyra austrotriadica Oberhauser; F - Endothyra keupperi Oberhauser; G - Endothyra gruenbachensis Oberhauser; H - Endothyra salaji Gaździcki; I - Trocholina blaui Senowbari-Daryan, Rashidi et Torabi; J - Trocholina umbo Frentzen; $\mathbf{K}$ - radial ooids and coated grains with serpulids and crinoids suggesting their storm-induced mixture with large-sized quartz grains; $\mathbf{L}$ - quartz grains with dark microbial rims developed as initial coated grains; $\mathbf{M}$ - quartz grains with micro-stromatolitic overgrowth showing the structure of cyanobacterial filaments; other explanations as in Figure 2 

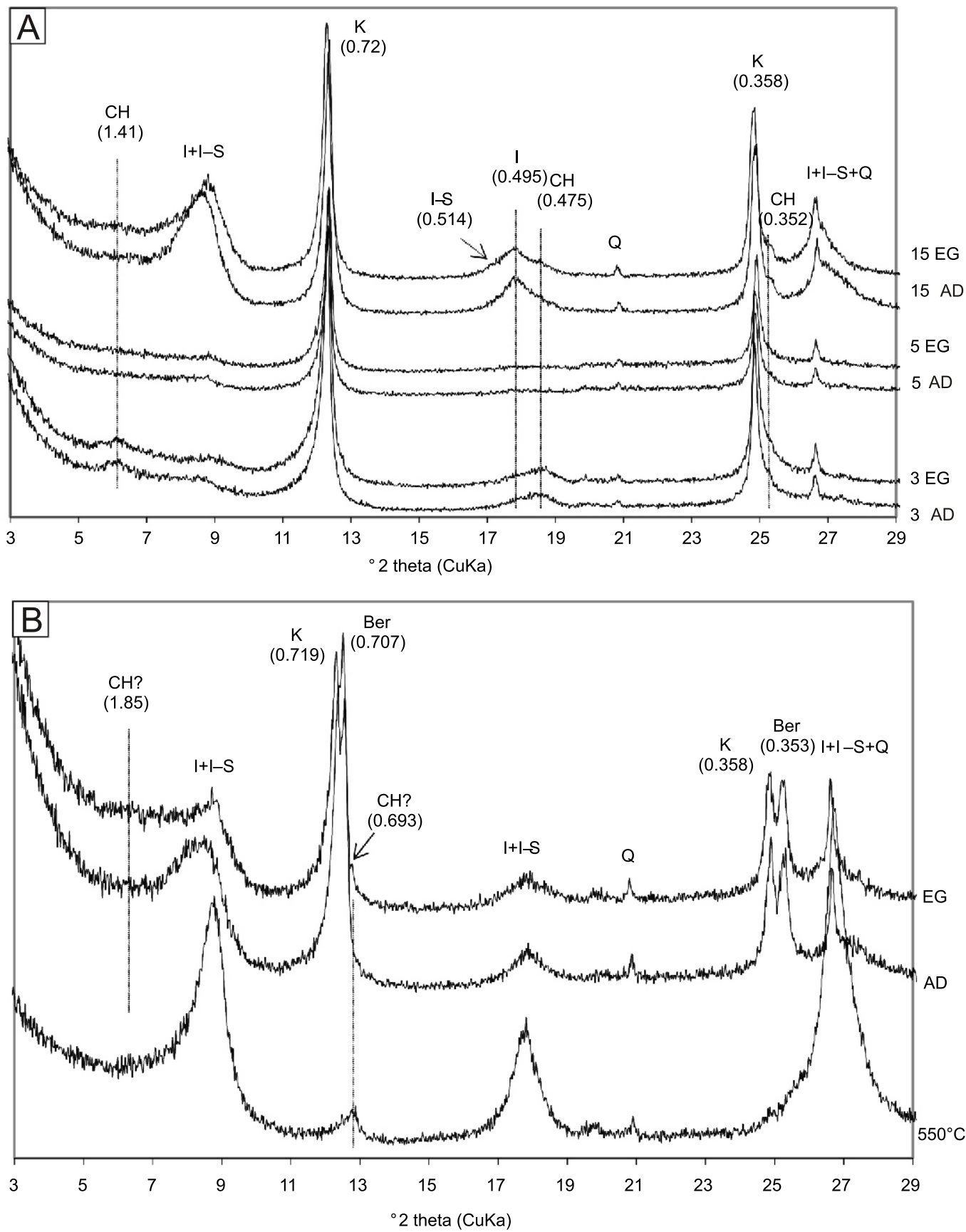

Fig. 9A - oriented XRD patterns of the clay fraction of the samples $3,5,15$, B - oriented XRD pattern of sample 14

$A D$ - air dried, Ber - berthierine, $\mathrm{CH}$ - chlorite, $\mathrm{EG}$ - ethylene glycol evaporised $\left(\mathrm{B}\right.$ - heated at $\left.550^{\circ} \mathrm{C}\right), \mathrm{I}-\mathrm{illite}$, I-S - illite-smectite, $\mathrm{K}$ - kaolinite, $\mathrm{Q}$ - quartz

MINERALOGY OF THE BULK ROCK

Quantitative mineral compositions of the bulk rock interpreted from XRD patterns of randomly oriented specimens with internal standard are shown in Table 2 and Figure 10. Quartz, kaolinite and 2:1 Al dioctahedral phyllosilicates (dioct 2:1: muscovite, illite, illite/smectite) represent the major mineral phases. These phases are interpreted as their sum because a precise quantitative distinction between dioct 2:1 phases is problematic. Quartz content is varies between 15 to $70 \mathrm{wt}$ \%. This wide range reflects a typical composition vs. grain size dependency of quartz in (silici)clastic sediments only (Fig. 10).
Kaolinite is the major clay mineral in the bulk fraction. According to XRD profiles, the structure of the kaolinites studied is disordered. Its content changed from 13 to $46 \mathrm{wt} . \%$ with average 32 wt.\% of 22 shale samples studied. Dioct 2:1 phyllosilicates are also present in significant amounts. The content of dioct 2:1 ranges from 5 to 39 wt. \% with average 17 wt.\% (Table 2). Generally, multiple sources and transport processes together with mutual dilution of individual clay minerals make it difficult to assign vertical changes of one clay mineral in the sequence as indicator of a single palaeoclimatic change. The comparison of two components by their ratio indicates the advantage of eliminating dilution effects by other components (Gingele et al., 
Table 1

Quantitative mineral composition of the clay fraction in selected samples

\begin{tabular}{|l|r|r|r|r|r|}
\hline \multirow{2}{*}{\multicolumn{1}{|c|}{ Minerals }} & \multicolumn{5}{|c|}{ Samples } \\
\cline { 2 - 6 } & CU3 & CU6c & CU8a & CU13 & CU15 \\
\cline { 2 - 6 } & \multicolumn{5}{|c|}{ [wt.\%] } \\
\hline Quartz & 3 & 4 & 4 & 4 & 5 \\
\hline Kaolinite & 57 & 58 & 58 & 65 & 41 \\
\hline $\begin{array}{l}\text { 2:1 Al dioctahedral } \\
\text { mica (illite + I-S) }\end{array}$ & 29 & 35 & 37 & 28 & 48 \\
\hline $\begin{array}{l}\text { Chlorite (Berthierine + } \\
\text { Fe chlorite) }\end{array}$ & 11 & 3 & 1 & 3 & 6 \\
\hline Sum [\%] & 100 & 100 & 100 & 100 & 100 \\
\hline
\end{tabular}

1998). The autor used a kaolinite/smectite ratio to estimate the extension of the river plume and intensity of water discharge in late Quaternary deposits. Here, the kaolinite/dioct 2:1 ratio is used as proxy of the parent rock composition and palaeoclimate and of the depositional environment and diagenesis. Values of the kaolinite/dioct 2:1 ratios show a decreasing trend up section (from 4.3 to 0.5 ) and increased dioct 2:1 content in the upper part of the section (Fig. 10), respectively.

The berthierine and probably the Fe-chlorite (chamosite) that are present in all samples represent the fourth mineral phase. However, according to the heating test and pattern fitting of the quantitative analyses berthierine is the dominant phase of these two Fe phyllosilicates. It is significant mainly in the part of the section that contains a larger amount of Fe phyllosilicates (from 5 to 24 wt.\%; samples 8-19). The highest amount is recorded in samples 14 and 15 (24 and 14 wt.\%). Fe carbonate (siderite) is the dominant phase in sample 13R (39 wt.\%). Siderite was determined in this sample together with other Fe miner-

Table 2

Quantitative mineral composition of the Tomanová Formation mudstones (beds 1-15) and from the Dudziniec Formation carbonates (beds 37-55)

\begin{tabular}{|c|c|c|c|c|c|c|c|c|c|c|}
\hline \multirow{2}{*}{$\begin{array}{c}\text { Minerals of the } \\
\text { Tomanová } \\
\text { Fm. }\end{array}$} & Quartz & Kaolinite & Mica* $^{*}$ & Chlorite & K-feldsp. & Biotite & Goethite** & Calcite & Siderite & \multirow{2}{*}{$\begin{array}{c}\text { Kaolinite } \\
\text { ratio }\end{array}$} \\
\hline & \multicolumn{9}{|c|}{ [wt.\%] } & \\
\hline CU1 & 70 & 19 & 6 & 3 & & 1 & & & & 3.2 \\
\hline CU2 & 44 & 43 & 10 & 3 & & & & & & 4.3 \\
\hline CU3 & 40 & 46 & 11 & 0 & 1 & & & & & 4.2 \\
\hline CU4 & 40 & 26 & 9 & 6 & 2 & 1 & 16 & & & 2.9 \\
\hline CU5 & 38 & 38 & 14 & 3 & 2 & 2 & 1 & & & 2.7 \\
\hline CU6 & 62 & 23 & 12 & 2 & & 1 & & & & 1.9 \\
\hline CU6b & 28 & 38 & 28 & 3 & & 1 & & & & 1.4 \\
\hline CU7 & 25 & 43 & 23 & 3 & & 2 & 1 & & & 1.9 \\
\hline CU8a & 25 & 43 & 23 & 5 & 1 & 1 & & & & 1.9 \\
\hline CU8b & 21 & 36 & 27 & 5 & & 2 & 6 & & & 1.3 \\
\hline VU9a & 24 & 42 & 21 & 6 & & 2 & 1 & & & 2.0 \\
\hline CU9b & 36 & 40 & 13 & 6 & 1 & 2 & 1 & & & 3.1 \\
\hline CU10a & 36 & 30 & 18 & 6 & 2 & 1 & 2 & & & 1.7 \\
\hline CU10b & 41 & 30 & 14 & 11 & & 1 & 1 & & & 2.1 \\
\hline CU11a & 29 & 35 & 26 & 7 & 1 & 1 & & & & 1.3 \\
\hline CU11b & 56 & 20 & 11 & 7 & & 0 & 0 & & & 1.8 \\
\hline CU12 & 49 & 25 & 13 & 5 & 1 & 2 & 4 & & & 1.9 \\
\hline CU13 & 40 & 35 & 16 & 7 & 1 & 1 & 1 & & & 2.2 \\
\hline CU13R & 15 & 13 & 5 & 7 & 1 & 2 & $11+4^{* *}$ & & 39 & 2.6 \\
\hline CU14 & 27 & 21 & 24 & 24 & 1 & 1 & 1 & & & 0.9 \\
\hline CU15 & 20 & 20 & 39 & 14 & 3 & 2 & 2 & & & 0.5 \\
\hline CU19 & 26 & 45 & 20 & 6 & 1 & 2 & & & & 2.3 \\
\hline Dudziniec Fm. & & & & & & & & Calcite & Dolomite & \\
\hline CU36 & 63 & 1 & 6 & 1 & & & 1 & 26 & 2 & 0.2 \\
\hline CU37 & 71 & 1 & 3 & 0 & & & & 24 & & 0.3 \\
\hline CU40 & 14 & 1 & 4 & 1 & & & & 79 & & 0.3 \\
\hline CU44 & 69 & 1 & 3 & 0 & & & & 26 & & 0.3 \\
\hline CU51 & 52 & & 16 & 3 & & & & 21 & 4 & 0.0 \\
\hline CU55 & 28 & & 14 & 4 & & & & 49 & 3 & 0.0 \\
\hline
\end{tabular}

${ }^{*}-2.1$ Al dioctahedral phyllosilicates, ${ }^{* *}-$ geothite + hematite 


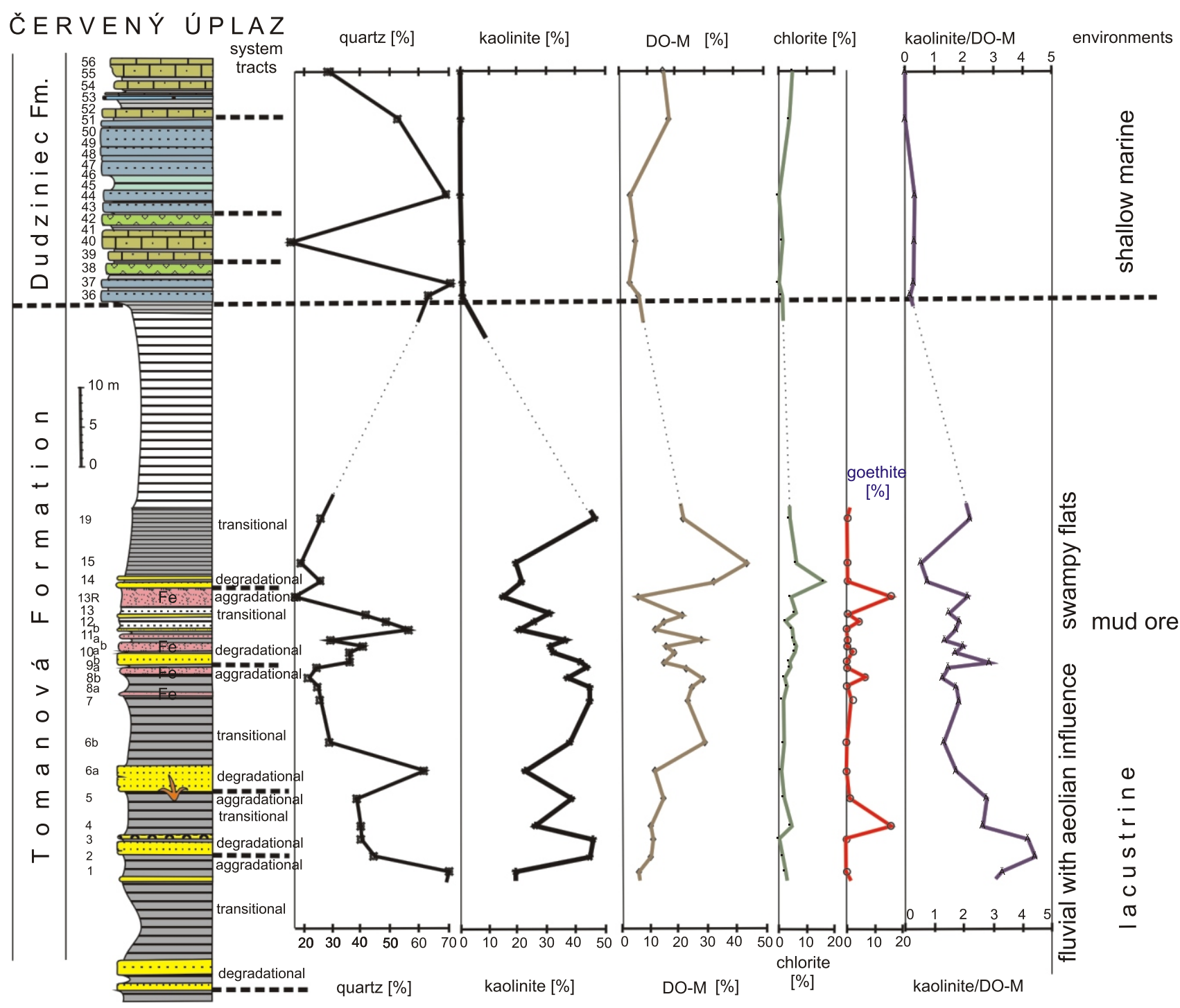

Fig. 10. Quantified content curves of quartz, kaolinite, dioctahedral 2:1 phyllosilicates (DO-M), chlorite, goethite in the bulk rocks and distribution of kaolinite/dioctahedral 2:1 phyllosilicate ratio (kaolinite/DO-M) integrated with sedimentology and lithofacies

Explanations as in Figure 2

als only: goethite (11 wt.\%) and hematite (4 wt.\%). Goethite was frequently identified in the samples studied but usually not in amounts more than $2 \mathrm{wt} . \%$. However, 9 wt.\% of goethite was determined in sample $4 a$, together with $\mathrm{Fe}$ phyllosilicates and lepidocrocite both at $6 \mathrm{wt}$ \%. This represents the highest proportion of Fe phyllosilicates in the lower part of the section investigated (Fig. 10; Table 2).

Biotite and K-feldspar were determined in most samples studied samples but they do not exceed 2 wt. \%. Albite, oligoclase, dolomite, anatase, rutile, ilmenite were detected only in trace amounts $(<1 \%)$ and these minerals are not shown in Table 2.

Quartz (14 to $71 \%$ ) and DO-M (6-4\%) were evaluated in the sequence overlying the Tomanová shale. Chlorite (0-4\%) and traces of kaolinite were only identified in the bulk rock samples. The beds are enriched in calcite (21 to $70 \%$; Table 2, Fig.11).

\section{CHEMISTRY}

\section{TOTAL CARBON AND C ISOTOPE ANALYSES}

Analyses document the content of the residual organic carbon $\left(\mathrm{C}_{\text {org }}\right)$ as proxy of organic matter production and accumulation (Fig. 11). In contrast to the statement of Radwański (1968), mudstones of the Tomanová Fm. are carbonate-free (Fig. 11). 


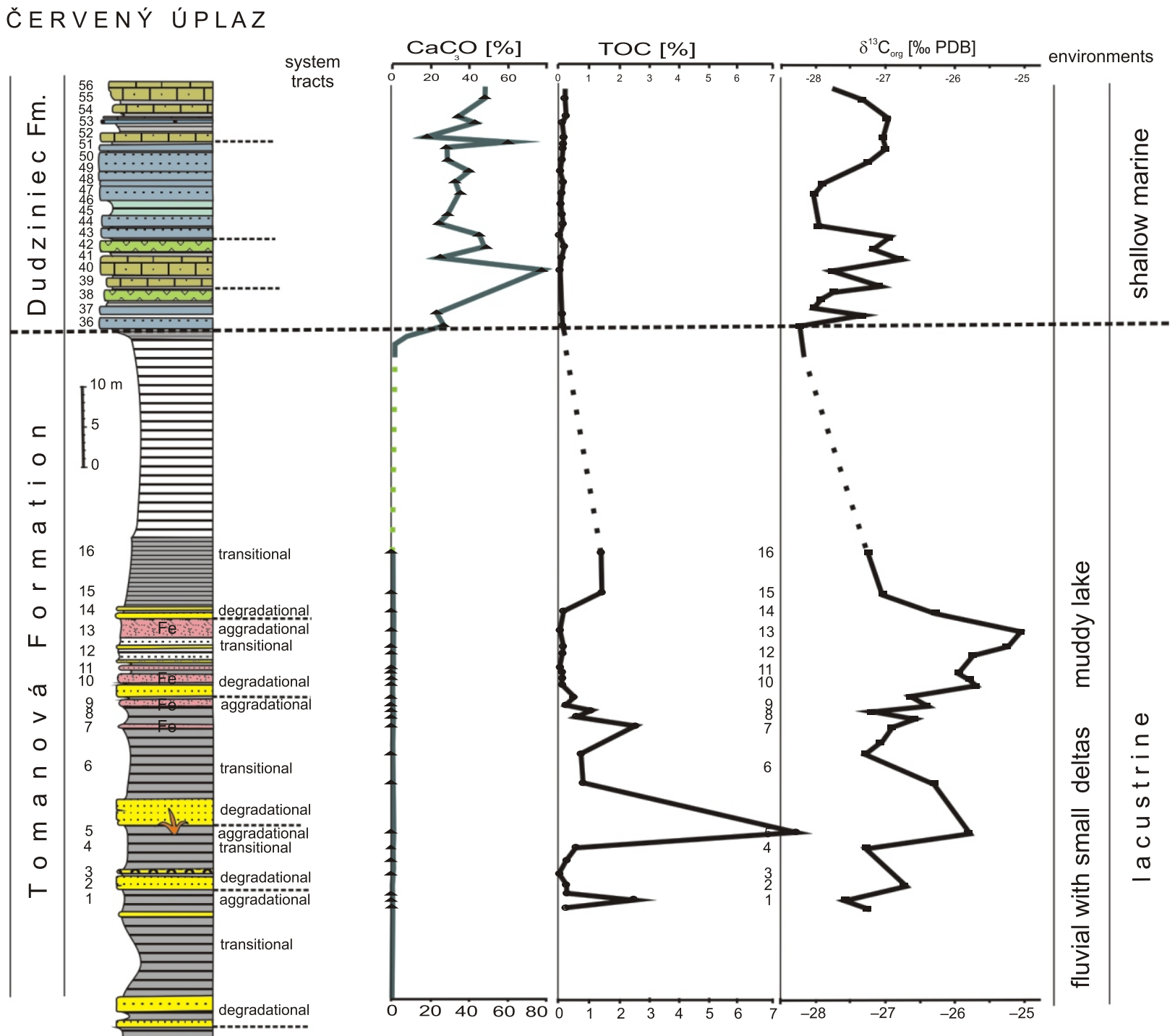

Fig. 11. Diagrams of total contents of organic (TOC) and inorganic carbon expressed as $\mathrm{CaCO}_{3}$, and $C$ isotope composition of the organic matter $\left(\delta^{13} C_{\text {org }}\right)$ integrated with sedimentology and lithofacies

\section{Explanations as in Figure 2}

Only in iron-rich mudstone (13R, 13R1) was carbonate identified and $39 \%$ of siderite has been quantified by XRD analysis (Table 2). In this mineralogical (Table 2) and microscopical study, inorganic carbon content has been adjusted to "stoichiometric calcite" in the samples from beds 36 to 55 (Fig. 10). The calcite contents vary widely (from 18 to $78 \%$, Fig. 11), mostly from 25 to $50 \%$. Despite that a content higher than $50 \%$ occurred only in two samples (40 and 51.5; Figs. 6 and 11) rocks of the Dudziniec Fm. designated as "carbonates" in the text bellow.

Although the content of residual organic carbon is relatively low $\left(\mathrm{C}_{\text {org }} 0.1-1.5 \%\right)$ it locally increases $(2.5 \%$ or $8.12 \%)$, indicating higher bio-production and/or organic matter input into the ba$\sin$ (Fig. 11). The highest $\mathrm{C}_{\text {org }}$ content is in bed 5 in which dinosaur traces have been discovered (Michalík et al., 1976; Michalík, 2003). Distribution of $\mathrm{C}_{\text {org }}$ or organic matter could coincide with the formation of sedimentary cycles as the oscillation of water level in a continental basin must have been strongly related to climate.
The shale $\delta^{13} \mathrm{C}_{\text {org }}$ isotope ratios are showen in the range from -27 to $-25 \%$ (VPDB; Fig. 11) and demonstrate that the organic matter derived from terrestrial plant debris was mixed with subaquatic organic matter in the sediments. The highest (more positive) values, which indicate plant debris dominance (Cerling et al., 1991; Shulte et al., 2011), were ascertained in beds 13 and 5 . The $\delta^{13} \mathrm{C}_{\text {org }}$ values of beds $46-55$ are more negative $(-27$ to $-28 \%$; Fig. 11), being comparable e.g., with values of organic matter analysed from shallow-marine carbonate and silicate rocks across the Triassic-Jurassic boundary sequence documented in the Zliechov Basin of the Fatric Unit (Michalík et al., 2011, 2013) and elsewhere (Pálfy et al., 2001; Hesselbo et al., 2002; Kuerschner et al., 2007). However, any speculation on the significance of the relative shift of $\delta^{13} C_{\text {org }}$ is limited by our ability to prove the stratigraphic continuity of the Tomanová Fm. mudstones and the carbonate sequence of the Dudziniec Fm. in the section studied. 


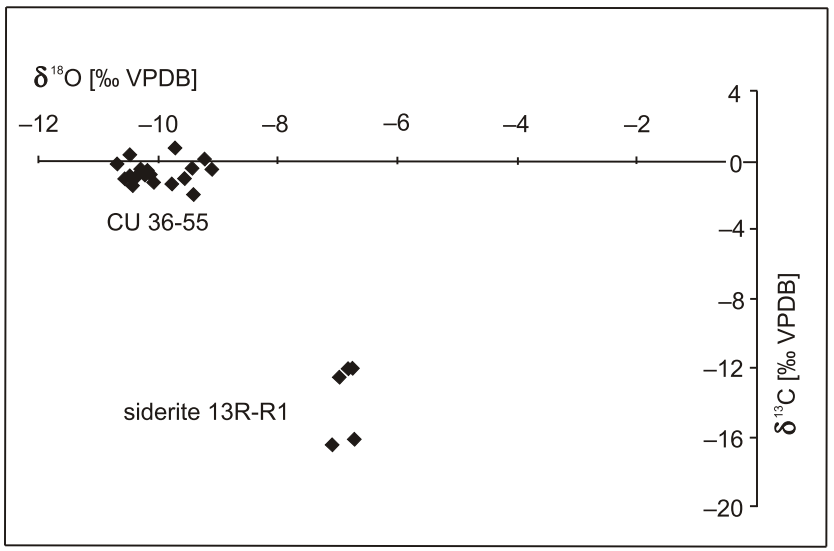

Fig. 12. Scatter diagram of carbonate isotopic composition

Comparison of $\mathrm{C}$ and $\mathrm{O}$ isotope composition of siderite (13R1 iron-rich mudstone ore sample) and other carbonates from beds 37 to 55 , disequlibrated by pluvial meteoric water during transgression

\section{SIDERITE - A PROXY OF HUMIDITY}

The carbon isotope data of the siderite $\delta^{13} \mathrm{C}_{\text {sid }}-12.0$ to $-16.4 \%$ VPDB (Fig. 12: 13R, 13R1) fall into data range of sphaerosiderite palaeosols ( +8 to $-45 \%$ ) as summarised by Sheldon and Tabor (2009). This wide span of data indicates recycling of microbial and especially methanogenic carbon in water-saturated (and dysoxic-anoxic) sediments or soils (White et al., 2001). According to this, the negative $\delta^{13} C_{\text {sid }}$ values of the Tomanová Formation suggest a complex C-isotope system where meteoric and soil $\mathrm{CO}_{2}$ were equilibrated with $\mathrm{CO}_{2}$ which came from bacterial methane oxidation. $\mathrm{C}_{\text {org }}$ is not elevated in bed 13 (Fig. 11), but methane and/or $\mathrm{CO}_{2}$ gases could locally have been easily released and penetrated through soil/sediment. In humid and Eh-reductive conditions, iron as ferrous ion was mobilised and siderite could precipitate in still, relative acid water/sediment conditions (for review see Sheldon and Tabor, 2009). The $\delta^{18} \mathrm{O}$ values (-6.7 to $-7.0 \%$ VPDB) in siderite are more negative as found in Cenozoic or recent soil sphaerosiderites (? -2.0\% PDB; Sheldon and Tabor, 2009). As usually observed, a heat permeated through buried (Rhaetian) beds for a substantially longer time and $\delta^{18} \mathrm{O}$ was shifted to more negative values. Although the $\delta^{18} \mathrm{O}$ shift suggests relative weak diagenetic alteration, the $\delta^{18} \mathrm{O}_{\text {sid }}$ (or soil $\delta^{18} \mathrm{O}$ calcite generally) values usually was not used as an independent thermometer (Cerling et al., 1991; Retallack, 2009). The siderite $\mathrm{C}$ and O isotope data (Fig. 12) document water-saturated conditions when iron rich mudstones formed in a humid climate (Andrews, 2006; Sheldon and Tabor, 2009).

\section{STABLE C AND O ISOTOPES OF CALCITE}

The isotope composition of the calcite-rich beds (37 to 55 ) is unusual $\left(\delta^{13} \mathrm{C}\right.$ from -1.98 to $+0.28 \%$ VPDB, $\delta^{18} \mathrm{O}$ from -10.69 to $-9.34 \%$ VPDB; Fig. 12) in comparison with marine limestones and also with calcite precipitates from meteoric water (riverine tufas, Andrews, 2006). More positive $\delta^{13} \mathrm{C}$ values occurred in bed 40 only with about a $80 \%$ content of $\mathrm{CaCO}_{3}$. Data are comparable to that of the siderite (Fig. 12). Re-equilibrated C and O isotope data are not in line with the typical isotope trend of meteoric water (Andrews, 2006; Schulte et al., 2011). Smith et al. (2004) found a similar shift of data in Pleistocene spring tufas (carbonates from the currently hyperarid Western Desert of Egypt) as indices of an earlier humid (pluvial) climate. In our section the strongly decreased $\delta^{18} \mathrm{O}$ isotope data together with the microstructural character (Figs. 6 and 12) may indicate diagenetic isotope fractionation in the water-sediment system. A large volume of buried meteoric water (pluvial events during transgression) may have modified the isotope composition of the marine carbonates. In sequel a large $\left(\right.$ as $\left.\delta^{13} \mathrm{C}_{\text {cal }}\right)$ negative $\delta^{18} \mathrm{O}_{\text {cal }}$ shift reflects temperature-dependent isotope fractionation of $\mathrm{O}$ isotopes during diagenesis.

\section{BULK ROCK CHEMICAL ANALYSES}

The bulk rock analyses (Table 3 ) of the selected samples were used to the compare sedimentary rock composition in the sequences and to test material and stratigraphic continuity of the sequences. Geochemical data may also be used as proxy for climate changes as discussed below.

Major and trace elements composition showed the chemical homogeneity of the mudstones and their difference to that of the overlying carbonates (Table 3). Enrichment of stable ( $\mathrm{Si}, \mathrm{Al}, \mathrm{Ti}$ ) and depletion of labile $(\mathrm{K}, \mathrm{Na}, \mathrm{Ca}, \mathrm{Mg})$ major elements are typical features of deeply weathered silicate rocks (Tables 3 and 4; Fig. 13). This was taken into account when comparing the chemistry of the samples with PAAS or with values of calculated indices (Tables 3 and 4). Low $\mathrm{Na}$ contents and relative weak $\mathrm{Na}_{2} \mathrm{O}-\mathrm{K}_{2} \mathrm{O}$ covariance (Fig. 13B) are the result of preferential $\mathrm{Na}$ removal from rock-minerals, in comparison to $\mathrm{K}$ (McLennan, 1993). High contents of Fe (23-48\%) are documented only at certain levels and signalised short-lived input of iron into the sediments (Fig. 13A). This "Fe event" reflects a wet climate (Sheldon and Tabor, 2009). Iron content is expressed as total $\mathrm{Fe}_{2} \mathrm{O}_{3}$ and only approximates $\mathrm{Fe}$ content in Fe-minerals (Tables 2 and 3 ). Because both ferric and ferrous ions are in the Fe-minerals, the total iron content could be lower than shown in the iron rich (Price and Velbel, 2003; Ohta and Arai, 2007). In comparison with the PAAS, increased $\mathrm{TiO}_{2}$ contents document $\mathrm{TiO}_{2}$ accumulation in mudrocks due to weathering. Minimal (about detection limit) contents of total $\mathrm{S}$ and $\mathrm{P}_{2} \mathrm{O}_{5}$ in the sequence are typical of products of intense chemical weathering in continental conditions (Otha and Arai, 2007; Sheldon and Tabor, 2009). The higher $\mathrm{MnO}$ in Fe- rich mudrock may be linked with specific redox dependent mobilization of $\mathrm{Fe}$ and $\mathrm{Mn}$ in sedimentary or diagenetic conditions in lacustrine basins (Table 3).

Contents of the large ion lithophile elements (LILE: Rb, Cs, $\mathrm{Sr}$ and $\mathrm{Ba}$ ) as elements with high affinity to alkali bases (Table 3 ) are fractionated by weathering. Figure $13 \mathrm{C}$ documents high co-variation of $\mathrm{Rb}$ with $\mathrm{K}$. The $\mathrm{K} / \mathrm{Rb}$ ratio values lower than PAAS (Table 4) also indicate relative $\mathrm{Rb}$ enrichment in the mudroks. The highest $\mathrm{Rb}$ content occurs in bed 15 with higher dioctahedral 2:1 phase (muscovite, illite) content. Content changes of other LILE - Cs, Sr and Ba analysed are not as evident as of $\mathrm{Rb}$ through the section. Cs has accumulated in the clay matrix while $\mathrm{Ba}$ is depleted as in PAAS (Table 3 ). Carbonate contents are linked with $\mathrm{Sr}$ and probably with $\mathrm{Ba}$ contents in the upper part of the section only.

High field strength elements (HFSE): $\mathrm{Y}, \mathrm{Hf}, \mathrm{Nb}, \mathrm{Th}, \mathrm{U}, \mathrm{Zr}$ and REE in the mudstones are enriched as in PAAS, slightly depleted in the Fe-rich mudstones and depleted in the limestone 
Results of bulk rock sample chemical analyses

\begin{tabular}{|c|c|c|c|c|c|c|c|c|c|c|c|c|c|c|}
\hline Samples & CU1 & CU3 & CU5 & CU7 & CU10A & CU13 & CU13R & CU13R1 & CU15 & CU37 & CU40 & CU44 & CU55 & PAAS \\
\hline Analyte & \multicolumn{14}{|c|}{ [wt.\%] } \\
\hline $\mathrm{SiO}_{2}$ & 57.24 & 62.94 & 56.33 & 54.73 & 58.61 & 63.02 & 23.77 & 43.12 & 51.5 & 75.55 & 20.71 & 70.74 & 63.54 & 62.80 \\
\hline $\mathrm{Al}_{2} \mathrm{O}_{3}$ & 25.94 & 23.3 & 19.5 & 26.2 & 21.55 & 21.82 & 7.13 & 13.33 & 25.75 & 2.29 & 2.37 & 2.15 & 11.67 & 18.90 \\
\hline $\mathrm{Fe}_{2} \mathrm{O}_{3}$ & 2.08 & 1.07 & 2.95 & 4.06 & 6.44 & 2.56 & 48.31 & 24.3 & 5.65 & 1.42 & 1.14 & 1.02 & 2.35 & 6.50 \\
\hline $\mathrm{MgO}$ & 0.49 & 0.38 & 0.23 & 0.65 & 0.65 & 0.75 & 0.98 & 1.92 & 0.81 & 0.15 & 0.73 & 0.22 & 0.98 & 2.20 \\
\hline $\mathrm{CaO}$ & 0.05 & 0.1 & 0.03 & 0.19 & 0.09 & 0.13 & 0.19 & 0.77 & 0.32 & 10.79 & 39.55 & 13.41 & 7.66 & 1.30 \\
\hline $\mathrm{Na}_{2} \mathrm{O}$ & 0.26 & 0.31 & 0.21 & 0.4 & 0.27 & 0.25 & 0.01 & 0.05 & 0.45 & 0.05 & 0.04 & 0.03 & 0.10 & 1.20 \\
\hline $\mathrm{K}_{2} \mathrm{O}$ & 1.32 & 0.63 & 0.78 & 1.21 & 0.93 & 0.89 & 0.21 & 0.41 & 2.83 & 0.43 & 0.70 & 0.54 & 3.24 & 3.70 \\
\hline $\mathrm{TiO}_{2}$ & 1.28 & 1.6 & 1.14 & 1.39 & 1.46 & 1.18 & 0.42 & 0.82 & 0.89 & 0.12 & 0.13 & 0.15 & 0.82 & 1.00 \\
\hline $\mathrm{P}_{2} \mathrm{O}_{5}$ & 0.03 & 0.03 & 0.04 & 0.04 & 0.03 & 0.02 & 0.02 & 0.03 & 0.03 & $<0.01$ & 0.03 & 0.02 & 0.07 & 0.11 \\
\hline $\mathrm{MnO}$ & $<0.01$ & $<0.01$ & $<0.01$ & $<0.01$ & 0.02 & $<0.01$ & 0.51 & 0.18 & 0.01 & 0.08 & 0.10 & 0.03 & 0.03 & 0.16 \\
\hline$S$ tot & 0.04 & $<0.02$ & 0.05 & $<0.02$ & $<0.02$ & $<0.02$ & $<0.02$ & $<0.02$ & 0.02 & $<0.02$ & 0.02 & $<0.02$ & 0.7 & \\
\hline LOI & 11.2 & 9.5 & 18.6 & 11 & 9.8 & 9.2 & 18.4 & 15.9 & 11.6 & 9.1 & 34.4 & 11.6 & 9.3 & \\
\hline$C$ tot & 0.4 & 0.27 & 7.4 & 0.53 & 0.22 & 1.46 & 3.96 & 3.51 & 1.46 & 2.24 & 9.43 & 2.85 & 1.76 & \\
\hline Analyte & \multicolumn{14}{|c|}{ [ppm] } \\
\hline $\mathrm{Ba}$ & 317 & 255 & 239 & 231 & 225 & 206 & 49 & 82 & 231 & 119 & 74 & 43 & 216 & 650 \\
\hline Co & 8.7 & 8.8 & 2.7 & 8.7 & 26.7 & 11.5 & 25.3 & 18.3 & 11.8 & 1.2 & 1.8 & 2.3 & 7.4 & 23 \\
\hline Cs & 19.2 & 9.9 & 15.2 & 16.1 & 13.5 & 11.6 & 2.9 & 4.6 & 16.9 & 0.3 & 1 & 0.7 & 8.3 & 4.6 \\
\hline $\mathrm{Cr}$ & 76 & 90 & 86 & 66 & 62 & 83 & 41 & 45 & 66 & 6.9 & 6.9 & 10.35 & 41.4 & 110 \\
\hline $\mathrm{Ga}$ & 32.4 & 30.8 & 25.6 & 32.2 & 27.8 & 27.7 & 8.4 & 15.3 & 34.3 & 0.8 & 1.4 & 1.4 & 12.8 & 20 \\
\hline $\mathrm{Hf}$ & 7.0 & 12.8 & 9.6 & 5.6 & 8.1 & 11.6 & 5.1 & 10.0 & 3.5 & 2.5 & 4.4 & 6.4 & 19.9 & 5.8 \\
\hline $\mathrm{Nb}$ & 35.4 & 42.2 & 30.3 & 34.9 & 35.4 & 29.1 & 12.2 & 19.2 & 23.9 & 2.2 & 2.5 & 2.1 & 18.2 & 19 \\
\hline $\mathrm{Ni}$ & 50 & 56 & $<20$ & 36 & 75 & 59 & 30 & 25 & 22 & 4.7 & 4.8 & 6.4 & 15.4 & 55 \\
\hline $\mathrm{Rb}$ & 84 & 40 & 64 & 88 & 68 & 59 & 13 & 26 & 158 & 13 & 21 & 18 & 111 & 160 \\
\hline Sc & 20 & 18 & 17 & 21 & 20 & 16 & 11 & 20 & 7 & 1 & 2 & 2 & 8 & 16 \\
\hline $\mathrm{Sr}$ & 41 & 39 & 46 & 48 & 36 & 35 & 15 & 29 & 58 & 44 & 272 & 62 & 82 & 200 \\
\hline Th & 22.5 & 24.5 & 18.7 & 25.9 & 32.7 & 24.5 & 8.8 & 17 & 14.7 & 3.2 & 4.5 & 5.9 & 16.1 & 14.6 \\
\hline$U$ & 6.7 & 15.6 & 23.3 & 5.5 & 5.6 & 4.3 & 4.5 & 4.5 & 3.7 & 0.7 & 1.1 & 1.5 & 4.4 & 3.1 \\
\hline V & 132 & 199 & 169 & 161 & 177 & 121 & 46 & 78 & 130 & 8 & 10 & 13 & 83 & 150 \\
\hline $\mathrm{Zr}$ & 245 & 460 & 357 & 207 & 297 & 411 & 180 & 363 & 120 & 99 & 164 & 252 & 730 & 210 \\
\hline Y & 33.5 & 44.4 & 49.6 & 41.8 & 44.1 & 44 & 28.2 & 39.1 & 28.7 & 5.1 & 8.1 & 8.6 & 26.2 & 27 \\
\hline $\mathrm{La}$ & 48.9 & 41.5 & 70.8 & 88.1 & 71.8 & 34.7 & 18.0 & 23.5 & 39.5 & 8.5 & 13.7 & 16.5 & 45.4 & 38.2 \\
\hline $\mathrm{Ce}$ & 102.6 & 96.2 & 154.2 & 165.5 & 187 & 72.5 & 40.5 & 51.8 & 79.5 & 14.7 & 27.5 & 32.4 & 90.8 & 79.6 \\
\hline $\mathrm{Pr}$ & 10.88 & 10.70 & 16.50 & 17.45 & 19.97 & 9.74 & 4.32 & 6.03 & 9.87 & 1.77 & 3.13 & 3.72 & 9.81 & 8.83 \\
\hline $\mathrm{Nd}$ & 41.3 & 37.5 & 58.1 & 61.5 & 73.1 & 41.3 & 16.4 & 25.1 & 37.0 & 5.5 & 11.4 & 15.2 & 34.8 & 33.9 \\
\hline $\mathrm{Sm}$ & 7.09 & 6.01 & 10.10 & 10.54 & 12.67 & 9.01 & 3.39 & 4.61 & 7.17 & 1.28 & 2.22 & 2.71 & 5.92 & 5.55 \\
\hline $\mathrm{Eu}$ & 1.27 & 1.08 & 1.97 & 1.91 & 2.31 & 2.50 & 1.93 & 1.49 & 1.28 & 0.20 & 0.35 & 0.26 & 0.76 & 1.08 \\
\hline $\mathrm{Gd}$ & 6.17 & 5.72 & 9.00 & 8.18 & 9.04 & 8.27 & 3.69 & 4.60 & 5.42 & 1.02 & 1.67 & 2.06 & 4.98 & 4.66 \\
\hline $\mathrm{Tb}$ & 1.07 & 1.19 & 1.60 & 1.38 & 1.47 & 1.31 & 0.73 & 0.94 & 0.89 & 0.13 & 0.26 & 0.29 & 0.77 & 0.774 \\
\hline Dy & 6.15 & 7.22 & 8.41 & 7.44 & 7.71 & 7.18 & 4.41 & 5.92 & 4.93 & 0.95 & 1.36 & 1.61 & 4.69 & 4.68 \\
\hline $\mathrm{Ho}$ & 1.23 & 1.58 & 1.68 & 1.51 & 1.59 & 1.46 & 1.00 & 1.35 & 0.99 & 0.15 & 0.26 & 0.27 & 0.93 & 0.991 \\
\hline $\mathrm{Er}$ & 3.52 & 4.65 & 4.54 & 4.21 & 4.50 & 4.16 & 2.84 & 3.74 & 2.97 & 0.49 & 0.70 & 0.87 & 3.21 & 2.85 \\
\hline $\mathrm{Tm}$ & 0.50 & 0.71 & 0.66 & 0.61 & 0.67 & 0.63 & 0.43 & 0.57 & 0.45 & 0.07 & 11.00 & 13.00 & 48.00 & 0.405 \\
\hline $\mathrm{Yb}$ & 3.34 & 4.66 & 4.09 & 3.76 & 4.43 & 3.94 & 2.69 & 3.67 & 2.92 & 0.42 & 0.81 & 0.93 & 3.44 & 2.82 \\
\hline $\mathrm{Lu}$ & 0.51 & 0.71 & 0.62 & 0.55 & 0.66 & 0.62 & 0.40 & 0.55 & 0.45 & 0.05 & 0.13 & 0.15 & 0.54 & 0.433 \\
\hline TREE & 234.5 & 219.4 & 342.3 & 372.4 & 396.9 & 197.3 & 100.7 & 133.9 & 193.3 & 35.23 & 63.6 & 77.1 & 206.53 & 184.77 \\
\hline LREE & 218.2 & 198.7 & 320.7 & 353.2 & 375.9 & 178.0 & 88.2 & 117.1 & 179.7 & 32.97 & 59.97 & 72.85 & 192.47 & 167.16 \\
\hline HREE & 16.3 & 20.7 & 21.6 & 19.5 & 21.0 & 19.3 & 12.5 & 16.7 & 13.6 & 2.26 & 3.69 & 4.25 & 14.06 & 17.613 \\
\hline
\end{tabular}


Table 4

List of indices calculated from data in the Table 3 (as molecular or wt. $\%$ mass ratios and normalized to PAAS)

\begin{tabular}{|c|c|c|c|c|c|c|c|c|c|c|c|c|c|c|}
\hline $\begin{array}{l}\text { Molecular } \\
\text { indices }\end{array}$ & CU1 & CU3 & CU5 & CU7 & CU10A & CU13 & CU13R & CU13R1 & CU15 & CU37 & CU40 & CU44 & CU55 & PAAS \\
\hline CIW & 98 & 97 & 98 & 96 & 97 & 97 & 95 & 89 & 95 & nd & nd & nd & nd & 0.81 \\
\hline $\mathrm{CIA}$ & 93 & 94 & 94 & 92 & 93 & 93 & 92 & 86 & 85 & nd & nd & nd & nd & 0.69 \\
\hline $\mathrm{K}_{2} \mathrm{O} / \mathrm{TiO}_{2}$ & 0.87 & 0.33 & 0.58 & 0.74 & 0.54 & 0.64 & 0.43 & 0.43 & 2.70 & 3.04 & 4.57 & 3.06 & 3.36 & 3.14 \\
\hline Ti/Al & 0.12 & 0.16 & 0.14 & 0.12 & 0.16 & 0.13 & 0.11 & 0.16 & 0.08 & 0.13 & 0.13 & 0.17 & 0.17 & 0.13 \\
\hline \multicolumn{15}{|c|}{ wt. $\%$ indices } \\
\hline $\mathrm{K} / \mathrm{Rb}$ & 65 & 65 & 50 & 57 & 56 & 62 & 65 & 65 & 73 & 135 & 134 & 125 & 119 & 95 \\
\hline $\mathrm{Rb} / \mathrm{Sr}$ & 2.0 & 1.0 & 1.4 & 1.8 & 1.9 & 1.7 & 0.9 & 0.9 & 2.7 & 0.3 & 0.1 & 0.3 & 1.4 & 0.8 \\
\hline $\mathrm{V} / \mathrm{V}+\mathrm{Ni}$ & 0.7 & 0.8 & 0.9 & 0.8 & 0.7 & 0.7 & 0.8 & 0.7 & 0.7 & 0.7 & 0.7 & 0.7 & 0.9 & 0.7 \\
\hline $\mathrm{Zr} / \mathrm{Hf}$ & 35 & 36 & 37 & 37 & 37 & 35 & 35 & 36 & 34 & 40 & 37 & 39 & 37 & \\
\hline $\mathrm{Zr} / \mathrm{Sc}$ & 12 & 26 & 21 & 10 & 15 & 26 & 16 & 18 & 17 & 99 & 82 & 126 & 91 & 13 \\
\hline Th/U & 3.4 & 1.6 & 0.8 & 4.7 & 5.8 & 5.7 & 2.0 & 3.8 & 4.0 & 4.6 & 4.1 & 3.9 & 3.7 & 4.7 \\
\hline $\mathrm{Th} / \mathrm{Sc}$ & 1.1 & 1.4 & 1.1 & 1.2 & 1.6 & 1.5 & 1.3 & 1.6 & 0.7 & 3.2 & 2.3 & 2.3 & 2.0 & 0.9 \\
\hline $\mathrm{Cr} / \mathrm{V}$ & 0.6 & 0.5 & 0.5 & 0.4 & 0.4 & 0.7 & 0.9 & 0.6 & 0.5 & 0.9 & 0.7 & 0.8 & 0.5 & 0.7 \\
\hline $\mathrm{Cr} / \mathrm{Th}$ & 0.7 & 0.8 & 2.5 & 1.2 & 0.6 & 0.8 & 1.3 & 1.3 & 1.2 & 1.1 & 1.7 & 1.3 & 1.7 & 7.5 \\
\hline $\mathrm{Y} / \mathrm{Ni}$ & 3.4 & 3.4 & 4.6 & 2.5 & 1.9 & 3.4 & 4.7 & 2.6 & 4.5 & 2.6 & 1.5 & 1.8 & 2.6 & 0.5 \\
\hline $\mathrm{La} / \mathrm{Th}$ & 2.2 & 1.7 & 3.8 & 3.4 & 2.2 & 1.4 & 2.0 & 1.4 & 2.7 & 2.7 & 3.0 & 2.8 & 2.8 & 2.6 \\
\hline
\end{tabular}

The data are used in diagrams; CIW - Chemical Index of Weathering, CIA - Chemical Index of Alteration

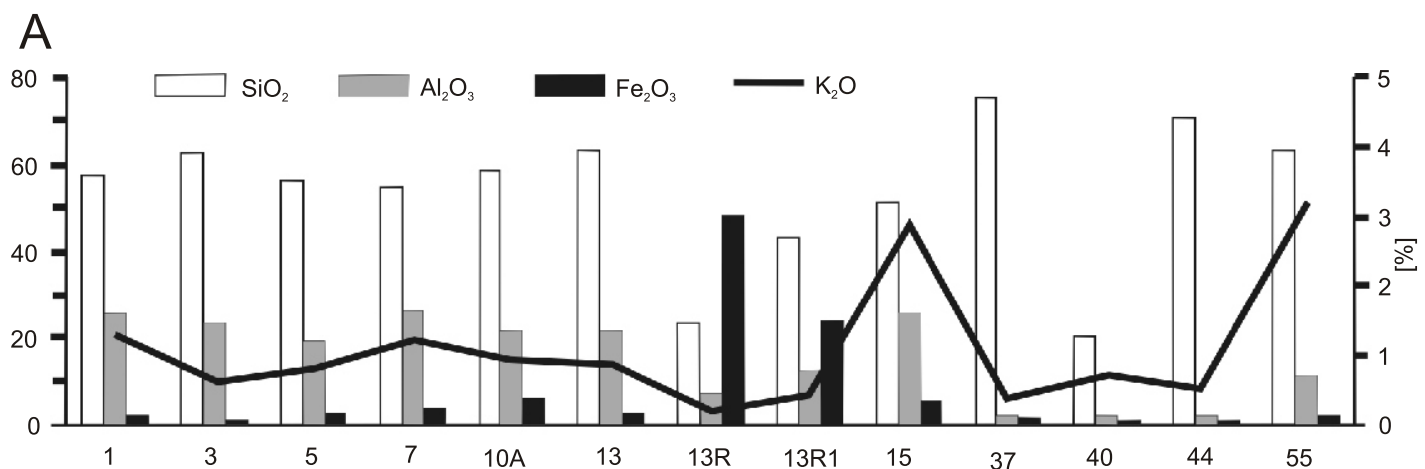

B

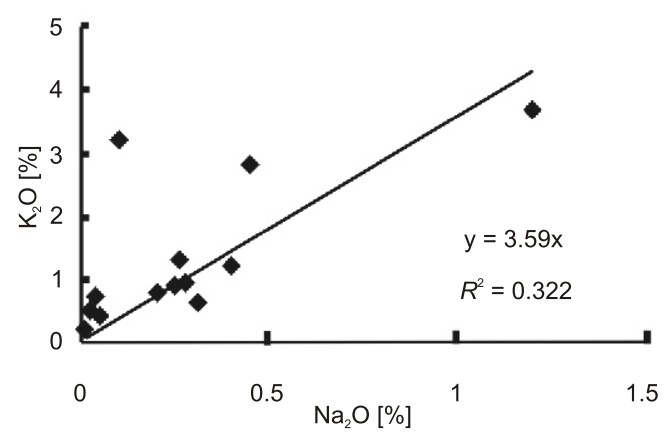

C

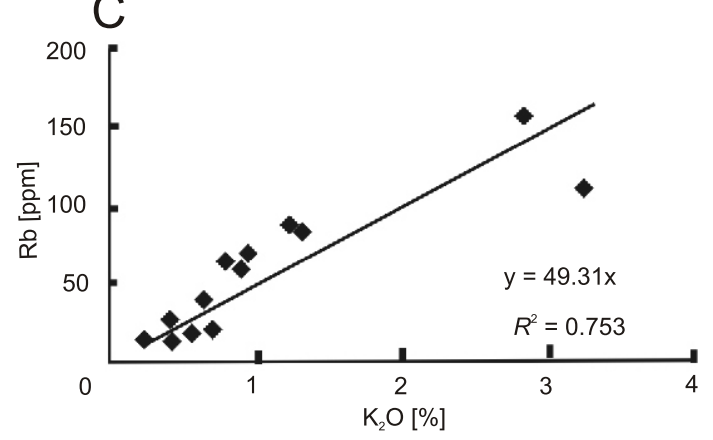

Fig. 13A - major element oxide distributions in the section, $\mathrm{K}_{2} \mathrm{O}$ variation documents different weathering and diagenetic history of bed 15 and increased silicate matrix in the beds 37 to 55; $\mathrm{B}$ - variation diagrams of $\mathrm{K}_{2} \mathrm{O}$ vs. $\mathrm{Na}_{2} \mathrm{O} ; \mathrm{C}-\mathrm{K}_{2} \mathrm{O}$ vs. $\mathrm{Rb}$ values 


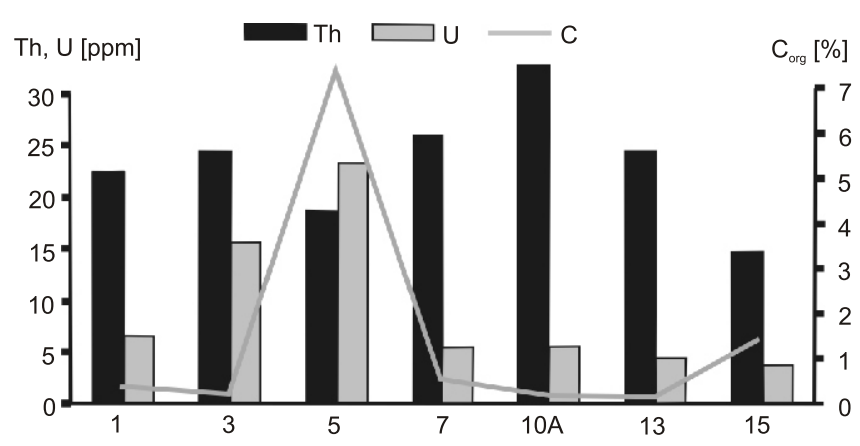

Fig. 14. Th, $\mathrm{U}$ and $\mathrm{C}_{\text {org }}$ distribution in mudstones of the Tomanová Fm.

samples (Table 3). Y, Hf, Nb, Th, $\mathrm{U}$ and $\mathrm{Zr}$ have been differentiated in the weathering process as suggested by strong covariance of $\mathrm{TiO}_{2}$ with $\mathrm{Nb}, \mathrm{Y}$ and $\mathrm{Th}\left(R^{2} ? 0.9, R^{2} ? 0.7, R^{2} ? 0.8\right)$ and weak with $\mathrm{U}, \mathrm{Zr}$ and $\mathrm{Hf}\left(R^{2}\right.$ ?0.3, $\left.R^{2} ? 0.2, R^{2} ? 0.2\right)$. Maximum $\mathrm{Zr}(460 \mathrm{ppm})$ and $\mathrm{Nb}(42.2 \mathrm{ppm})$ contents occurred in bed 3 with a high kaolinite content, and depletion of $\mathrm{Zr}$ and $\mathrm{Nb}$ occurred in bed 15 with high dioct 2:1 phyllosilicates and some K-feldspar.This could suggest $\mathrm{Nb}, \mathrm{Y}$, Th fixation together with $\mathrm{Ti}$ in the clays. Higher $\mathrm{Th} / \mathrm{U}$ values (>4, Table 4 ) documents intense weathering (McLennan et al., 1993), but uranium positive variation with $\mathrm{C}_{\text {org }}$ indicates additional redox-related $\mathrm{U}$ differentiation in the sedimentary basin (Fig. 14).

Total REE (TREE) content of samples is higher than in PAAS (Nesbitt and Markovics, 1997; Galbarczyk-Gąsiorowska, 2010), especially the concentration of the light REE (LREE) in beds 5,7 and 10 , as is also reflected by relative higher $\mathrm{Ce}^{*}$ values there (Table 3; Fig. 15). TREE depletion relative to PAAS and no or positive Eu-anomalies characterise Fe rich mudstone

A

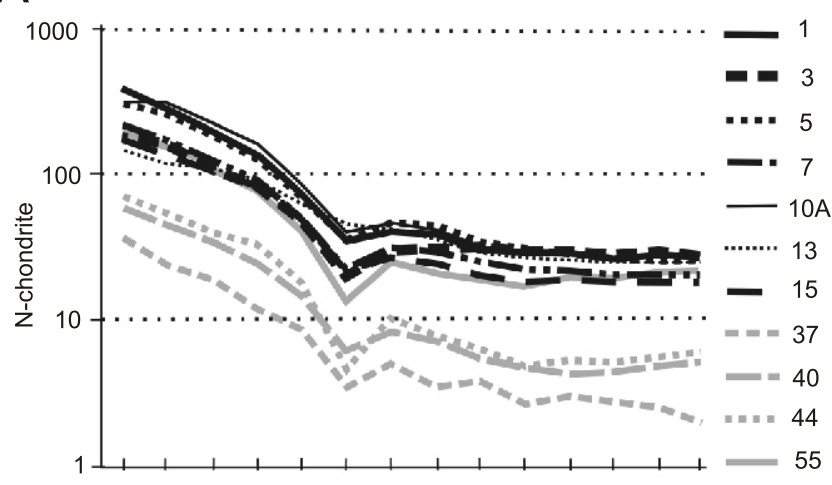

La Ce Pr Nd Sm Eu Gd Tb Dy Ho Er Tm Yb Lu

C

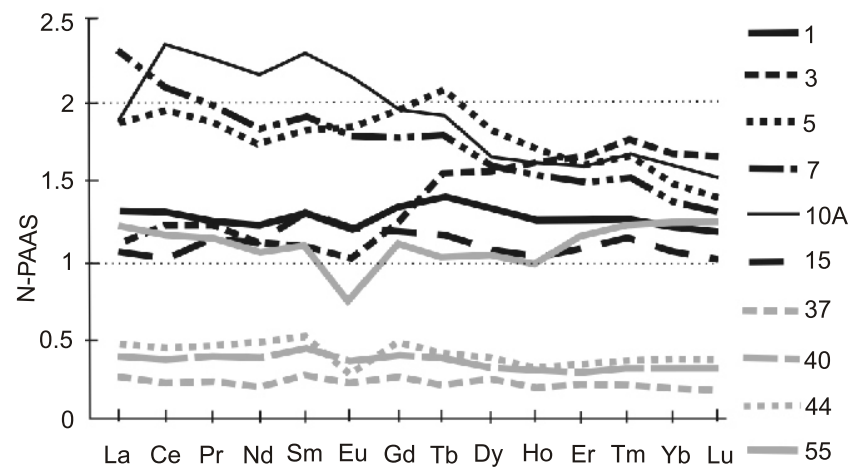

samples (Table 3; Fig. 15B, D). REE accumulated in silicates and only Eu as a redox sensitive element was mobilised in favourable conditions, as noted above (Sheldon and Tabor, 2009). TREE content increased with raised dioct 2:1 silicate contents in carbonate beds (Fig. 15A, C).

\section{DISCUSSION}

\section{CHEMICAL ANALYSIS AS A PROXY OF SOURCE ROCK WEATHERING}

The high CIW and CIA values, higher than in PAAS (Table 4) are quite generally typical of weathered kaolinite-enriched profiles (e.g., Nesbitt and Young, 1984; Condie, 1993; Cullers, 2000; Ohta and Arai, 2007) generated in a temperate humid climate. The higher $\mathrm{K}_{2} \mathrm{O}$ content slightly decreased the CIA value of bed 15 in comparison with other (carbonate free) mudrocks. Chemical index of alteration values are in accordance with the bed mineralogy (K-feldspar, dioctahedral 2:1 phyllosilicates; Table 2). The shifts of $\mathrm{CWI}$ and $\mathrm{ClA}$ values reflect $\mathrm{Ca}-\mathrm{Fe}$ substitution in siderite of the Fe-rich mudrocks samples (13R, 13R1). Because calcite occurred in beds 37, 40, 44 and 55 (Table 2; Figs. 10 and 11) the CIW and CIA indices were not calculated and other indices have been used for comparison.

$\mathrm{Ti}$ and $\mathrm{Al}$ can be used as proxies of relative chemical and mechanical weathering intensity of source rocks in mudstones and carbonate sequences (McLennan et al., 1993; Mongelli et al., 2006). Ti is fractioned in Ti-oxides (identified in XRD pattern) and clays as indicated by low but varied $\mathrm{Ti} / \mathrm{Al}$ values in the mudstones (Table 4). Decreased Ti/Al together with higher $\mathrm{K}_{2} \mathrm{O} / \mathrm{TiO}_{2}$ in bed 15 reflects relative weathering intensity. Analogically, $\mathrm{K}_{2} \mathrm{O} / \mathrm{TiO}_{2}$ and Ti/Al values in bed $37-55$, higher than in PAAS indicate a different "history" of weathering and sedimenta-

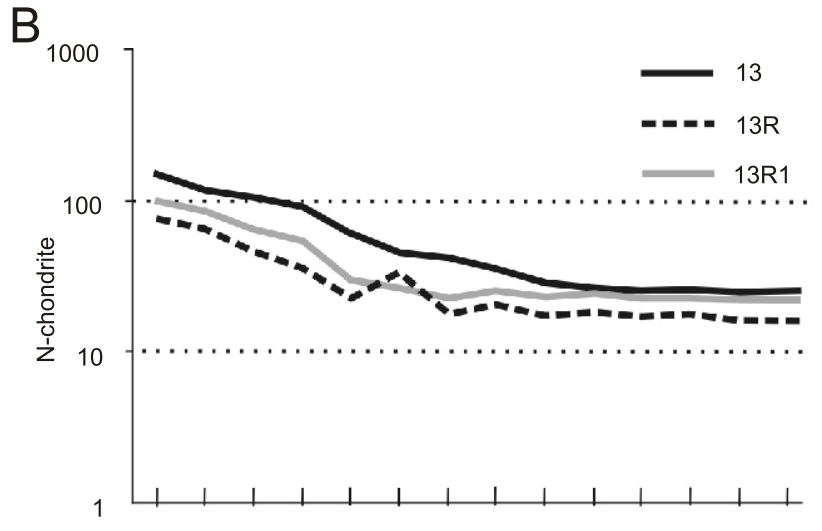

La Ce Pr Nd Sm Eu Gd Tb Dy Ho Er Tm Yb Lu

D

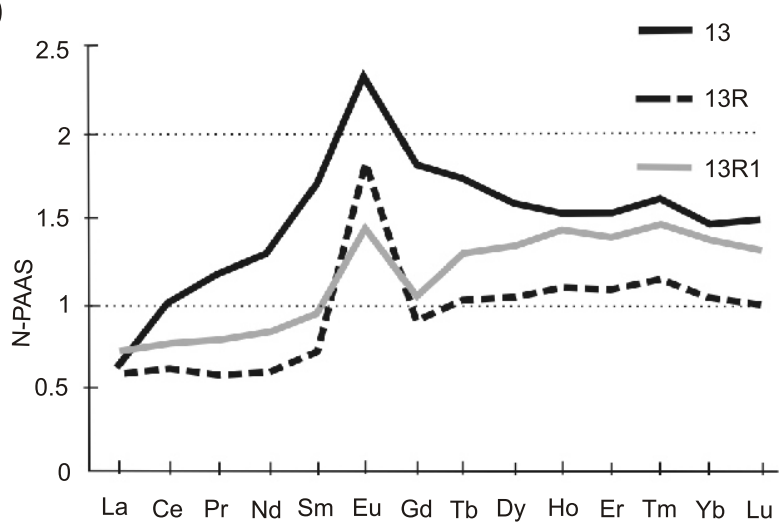

Fig. 15. N-chondrite and N-PAAS patterns from the Červený Úplaz samples 
tion. Intensity of parent rock weathering is indicated by the $\mathrm{Rb} / \mathrm{Sr}$ ratio, or $\mathrm{K} / \mathrm{Rb}$ ratio is used respectively because of the potential Sr affinity to Ca in calcite (McLennan et al., 1993; Vd'ačný et al., 2013). The $\mathrm{Rb} / \mathrm{Sr}$ values are higher than in PAAS (Table 4) and in combination with mudstones mineralogy they may denote the depth of weathered rock erosion and material sorting if the same rock source is informed. Changes in mudstones $\mathrm{K} / \mathrm{Rb}$ ratios are smaller (on average 61, 73 in bed 15) as in silicate of the limestone beds (119-134).

There is relative good correlation between LREE and quantified clay content $\left(R^{2}=0.34\right)$ of shale beds. Nevertheless, LREE accumulation in kaolinite or in illitic minerals could not be simply documented (Nesbitt et al., 1990; Honty et al., 2008). Correlation between quartz contents and HREE is more tight $\left(R^{2}=0.78\right)$.
HREE correlates better with Ti, Th, Y, Zr and indicates occurrence in "heavy minerals".

\section{REWORKING}

The chemical composition of the deposits has been affected by mechanical sorting and recycling (Cullers, 2000; Mongelli et al., 2006; Vd’ačný et al., 2013). Besides varying Ti-HFSE distributions, raised $\mathrm{Zr}$ content and near-chondrite values of $\mathrm{Zr} / \mathrm{Hf}$ ratio (34-40) in all samples (Table 4) indicate zircon occurrence or mechanical sorting in the sequence, respectively. The Al-Ti-Zr diagram (Fig. 16A) indicates shales (circles) similar to PAAS and slight variation in the sand/clay ratios (Figs. 4 and 6; Table 2;
B

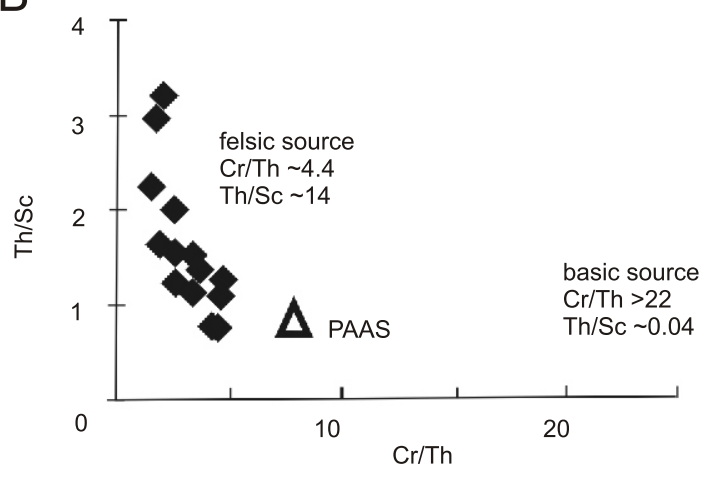

D

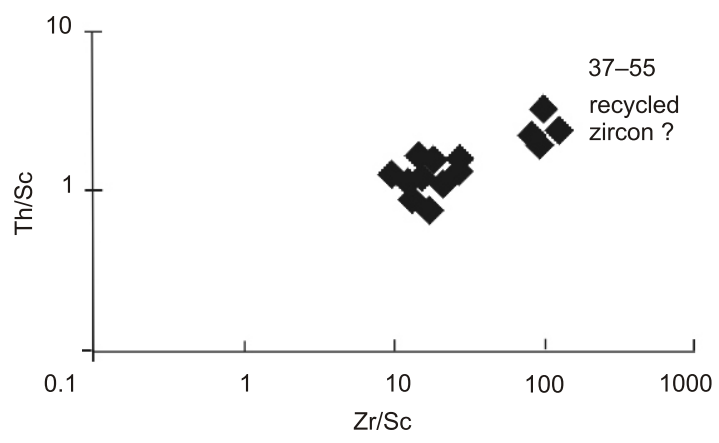

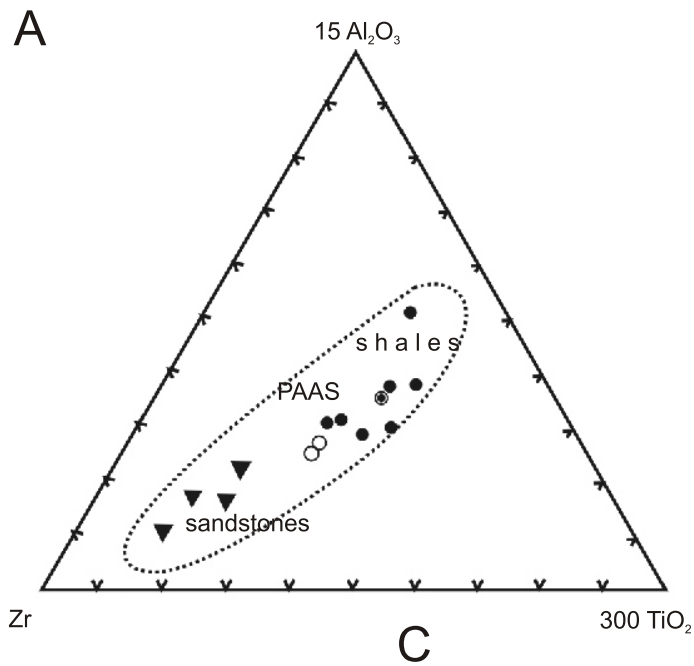

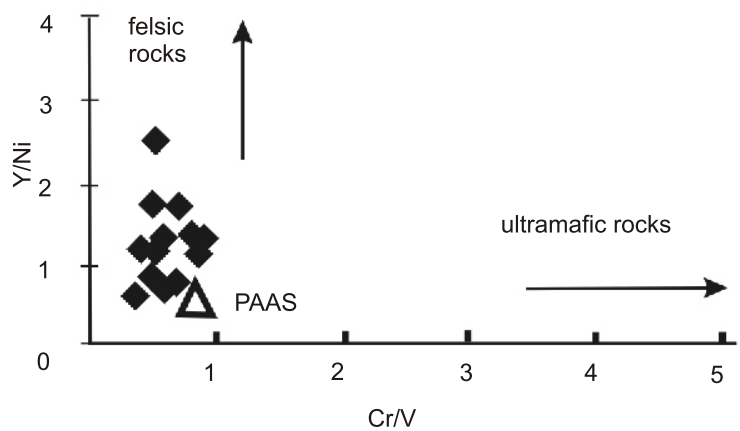

$E$

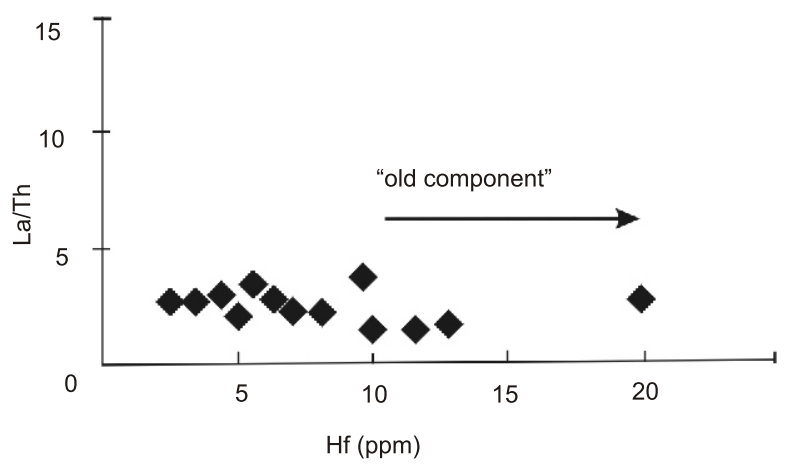

Fig. 16A - triangular Ti-Al-Zr plot of Červený Úplaz samples; B-E - scatter diagrams of trace element distribution as weathering and provenance proxy 
Garcia et al., 1994). As usual, Al-enriched (dioct 2:1 mica and illite) bed 15 is shifted more, but Fe-rich mudstones (sphaerosiderite - empty circles; Fig 16A) is located inside of the shale set. The positions of samples 37-55 (triangles) are relative shifted to sandstones in the diagrams, indicating recycled material. This could be supported also by the sample set position in Figure 16D, E. Th/Sc vs. Zr/Sc diagram (Fig. 16D; Mongelli et al., 2006) shows two sets and suggest $\mathrm{Zr}$ (probable as zircon) accumulation in gravity sorted quartz sand-fraction. A freshwater event at the beginning of the marine transgression is indicated by lithological data and by stable isotopes (Figs. 4, 8 and 12). La/Th vs. Hf (Fig. 16E) also indicates sorting and increased $\mathrm{Hf}$ content in recycled sedimentary material from the hinterland.

\section{PROVENANCE}

The chondrite-normalised (N-chondrite) REE diagrams show two potential sources, because a negative "Eu-anomaly" is typical of felsic (granites) and an absent or positive Eu anomaly characterizes mafic parent rocks (Fig. 15A, B). However, the patterns without the Eu anomaly belong to Fe-rich mudstones (13R, 13R1), where Eh-redox condition and probable Fe oxides (MacRae et al., 1992; Galbarczyk-Gasiorowska, 2010) changed REE patterns (Fig. 15B, D). REE patterns of the common shale where LREE are hundred times higher and HREE are ten times higher than in a chondrite with typical negative Eu anomalies are typical to mudrocks. This trend documents the mixing of continental sources during erosion and deposition of material (Condie, 1993; Cullers, 2000). Calcareous sandstones are depleted in REE but detailed N-PAAS patterns (Fig. 15A, C) did not recover the REE trend typical of marine carbonate where MREE accumulate (in phosphates) or are enriched by diagenesis (Shields and Webb, 2004; Haley et al., 2004; Ounis et al., 2008; Michalík et al., 2013). The REE-pattern of beds 37 to 44 can be regarded as a sign of recycled silicates only (Fig. 16A, D, C). As dioct 2:1 mica and illite content increased the REE pattern (bed $55)$ has taken the character of continental shales.

The character of the protolith is also indicated by metals compatible to $\mathrm{Mg}$ and $\mathrm{Fe}$ (Ni, $\mathrm{Co}, \mathrm{Cr}, \mathrm{V}$, and $\mathrm{Sc}$ ) and other HFSE ( $\mathrm{Y}, \mathrm{Hf}, \mathrm{Th}, \mathrm{Zr}$ ). The diagram of $\mathrm{Th} / \mathrm{Sc}$ vs. $\mathrm{Cr} / \mathrm{Th}$ ratios shows (Fig. 16B) that shales fall into the field of felsic parent rocks (Condie, 1993; Cullers, 2000; Mongelli et al., 2006). The Cr/V vs. Y/Ni (Fig. 16C) variation signalises a composition comparable to PAAS and a felsic source again. The iron-rich mudstones with dominant $\mathrm{Fe}^{2+}$ minerals are relatively depleted in $\mathrm{V}, \mathrm{Ni}$ (and $\mathrm{U}$ ), but their values do not change and indicate that these elements were concentrated in weathered silicates derived from felsic protolith. The recycled character of the upper part of the sequence suggests a different source and provenance of the sediment (Fig. 16D, E). However, a relative increase $\mathrm{Hf}$ and a higher $\mathrm{Zr} / \mathrm{Sc}$ ratio in the beds suggest only felsic or mixed felsic (magmatic or metamorphic) material from passive continental sources but not volcanic rocks (Floyd and Leveridge, 1987).

\section{SEDIMENTARY AND CLIMATIC CONDITIONS}

Organic matter accumulation was facilitated by a humid climate when larger flooded areas created optimal conditions for palustrine vegetation. Coal horizons and laminae with plant root remains could indicate palaeosols (fossil soils) which have been subsequently eroded (Michalík et al., 1988). The cycle lithology is consistent with periodic changes (deepening and shallowing) with fluvial input of organic matter from sporadically flooded areas. Distribution of redox-sensitive elements and organic matter are used to specify sedimentary conditions. While the lack of sul- phur or the Fe-enrichment in the sequence cannot represent a simple sedimentary signal (being a probable result of deep weathering, lacustrine water saturation, volcanic input, oxic conditions), trace elements $-\mathrm{U}, \mathrm{V}, \mathrm{Ni}$, Eu and their ratios are more recalling (Table 3 and 4). Higher contents of $U$ and other elements were recorded in these "black shales" by Michalík et al. (1988). The content of $U$ (higher than in PAAS) indicates $U$ mobilization in a sedimentary basin due to production of biomass and accumulation of organic matter (Table 4; Fig. 14). Low to negative $U$ vs. $V$ and $V / V+N i$ with $C_{\text {org }}$ variation occurred in the succession. The $\mathrm{V} / \mathrm{V}+\mathrm{Ni}$ (Table 4) data do not change through the section indicating consistent link of $\mathrm{V}$ and $\mathrm{Ni}$ with the parent rock weathering and generated clays and no mobilization due to organic matter accumulation in a sedimentary basin. The iron-rich mudstones samples are relative more depleted in $\mathrm{V}$ and $\mathrm{Ni}$ because new-formed siderite diluted the clay. Mudstones samples are slightly enriched in $\mathrm{U}, \mathrm{Mn}$ and $\mathrm{Co}$ (Table 3 ) and some $\mathrm{U}, \mathrm{Mn}$ and Co mobilization in the sedimentary basin can be supposed. The palaeosol siderite (Sheldon and Tabor, 2009) formed in Eh-reduced and $\mathrm{pH}$-acidic chemical systems which developed during wet and bio-productive times. The elements may have been leached and gained by newly formed or surface-active minerals. The Eu distribution in the section (Table 3; Fig. 15B, D) and high positive Eu anomaly in the Fe-rich mudstones samples reflects the more Eh-reduced but mainly $\mathrm{HCO}_{3}^{-}$saturated realm where Eu was selectively remobilised and enriched the Fe-enriched mudstones. Other REE distributions (Table 3; Fig. 15) indicates an enrichment during weathering process only.

\section{BURIAL HISTORY AND PALAEO-RECONSTRUCTION}

Assemblages of clay minerals are used as a tool for reconstruction of palaeoclimate and palaeoenvironment in various sedimentary models (e.g., Chamley, 1989; Weaver, 1989; Gingele et al., 1998; Heimhofer et al., 2008; Bristow et al., 2009). Kaolinite, illitic minerals, berthierine and chlorite have been determined in the Tomanová Fm. of the Červený Úplaz ravine (Table 2; Figs. 9 and 10). They can be authigenic but also detrital.

Continuous illitization of smectite via intermediate mixed-layer illite-smectite (I-S) is among to the most important phenomena of burial history of shales (Kisch, 1983; Środoń and Eberl, 1984). Illitic I-S (10-15\% of smectitic interlayers) was determined in the section studied. This stage of illitization could result from the burial temperature (about $180-200^{\circ} \mathrm{C}$; Polastro, 1993; Sucha et al., 1993). However, we do not infer that the studied sediments experienced late diagenesis because of the presence of berthierine which is a typical mineral of very early diagenesis (Odin et al., 1988; Morad et al., 2000). It is transformed to chamosite at temperature over $70^{\circ} \mathrm{C}$ (Hillier, 1994; Hornibrook and Longstaffe, 1996). I-S and chlorite are assumed as detrital mineral phases that did not undergo significant changes after deposition. The presence of disordered kaolinite, the major clay mineral in the section studied, also supports the assumption that the Červený Úplaz ravine clay minerals were not markedly transformed after deposition. Kaolinite is a typical product of lateritic weathering in a warm climate where precipitation is greater than $80-120 \mathrm{~cm}$ per year (Chamley, 1989; Weaver, 1989). The triclinic structure of kaolinite from the weathering zone is destroyed during erosion, transport, sedimentation and early diagenesis to disordered kaolinite (Shutov et al., 1970; Kisch, 1983). The initial structure is recovered and consecutively transformed to dickite. Kaolinite is very often neo-formed at an early stage of diagenesis and, subsequently, it may be transformed to illite during late diagenesis. However, these processes 
are characteristically of porous, sandy rocks. Kaolinite disappears with burial depth (Kisch, 1983; Lanson et al., 2001). None of these features were observed, except the presence of disordered kaolinite. This indicates rather a residual origin of the kaolinite.

As mentioned above, berthierine is an authigenic clay mineral in the section studied. Berthierine forms in shallow-water marginal marine or estuarine and deltaic sediments in a warm subtropical climate (Odin et al., 1988; Weaver, 1989; Hornibrook and Longstaffe, 1996; Morad et al., 2000). It requires an iron supply and anoxic conditions, but they should be marginally more oxic than the environment in which siderite precipitates. The amount of siderite (39 wt.\%; Table 4, Fig. 10) in sample $13 R$ is a proxy of increasing anoxia. A significant amount of kaolinite, over $30 \mathrm{wt} \%$ on average, also indicates a marginal depositional environment between continental and marine in a warm and humid climate. A decrease in the kaolinite vs. 2:1 Al dioctahedral phyllosilicates ratio upwards in the section reflects changes in the weathered host rock and/or increasing salinity of the transporting river. Illite flocculation and deposition rate increase with increases in salinity in comparison with kaolinite (Weaver, 1989) and settle out a little faster. Comparable clay mineral distributions except for presence of the berthierine have been reported by several authors (Ahlberg et al., 2003; Michalík et al., 2010; Zajzon et al., 2012) from Triassic-Jurassic boundary sections. However, the striking difference between the mineralogy of the Rhaetian Tomanová and Dudziniec formations (Table 2) suggests a sedimentary gap connected with a marine transgression.

\section{PALAEOGEOGRAPHICAL POSITION OF THE AREA}

Kaolin weathering crusts formed during the latest Triassic to Early Jurassic worldwide can be potentially used as climatic and palaeogeographic proxy of the $\mathrm{T} / \mathrm{J}$ boundary sequence and long-distance basin correlation (Ruffell et al., 2002; Prochnov et al., 2006; Dera et al., 2009; Michalík et al., 2010; Zajzon et al., 2012). In Central Europe, the kaolin province comprised a part of the Bohemian Massif and part of the Baltic Shield (e.g., Chamley, 1989; Kraus, 1989; Ahlberg et al., 2002, 2003; Brański, 2009). By contrast kaolin and kaolin clays occurring in a wider area along the northern Tethyan shore are stratigraphically uncertain, being mostly redeposited. The complex geological evolution of the Alpine Belt was not favourable either for preservation of kaolin weathering crust or for identification of hypergene kaolinitization.

During latest Triassic and early Jurassic times, redeposited kaolinite was preserved in the Western Carpathians only (Kraus, 1989). Quantitative sedimentological, mineralogical and geochemical characteristics indicate redeposition of kaolin sediments from the former weathering crusts. They originated from parent felsic rocks of the adjacent continent in a warm humid climate. Both the transport and the accumulation of material in sedimentary basins were climate-controlled as shown by the cyclic sedimentation, distribution and detrital character of the clay, properties of the quartz grains and geochemical parameters.

The intensity of diagenetic change of the sediment documented by clay minerals is notably low and suitable for palaeoclimatic and palaeogeographic deductions. The presence of kaolinite, mainly berthierine, documents sedimentary conditions. Berthierine along with siderite points to reduction conditions in sediment reflecting accumulation of organic matter. This conclusion is supported by geochemical parameters such as the distribution of redox-sensitive elements. Thus, the Tomanová Formation was deposited in a regime affected by increasing hu- midity (if compared with Carnian and Norian models) and by atmospheric changes associated with the beginning of CAMP volcanism worldwide (McRoberts et al., 1997; Pálfy et al., 2001; Hautmann, 2004; Huynh and Poulsen, 2005; McElwain et al., 2007; Berner and Beerling, 2007; Ruckwied and Götz, 2009 Haas et al., 2010).

In the Tethyan shelf area, the Tatric Zone as a part of Variscan consolidated belt occupied a special position (Fig. 17). Due to its thick sialic basement this block was elevated, emerged and exposed to kaolin weathering during the Late Triassic (Szulc in Feist-Burkhardt et al., 2008). Kaolin bearing sediments occur in a secondary position on several localities, but with the exception of the Tomanová Fm. (Michalík et al., 1976, 1988; Środoń et al., 2006) they have not been studied in detail yet.

The resulting model resembles the conclusions of FeistBurkhardt et al. (2008, including their figure 13.15) explaining the regime in the German Keuper Basin by periodic (400 ka eccentricity cycles) "mega-monsoonal" circulation from the Tethyan Ocean impinging on the Vindelician mountain belt. This model (Fig. 17) would explain the climatically controlled cyclicity with semiarid and humid intervals observed in our section and "pluvialized" conditions (Feist-Burkhardt et al., 2008) triggering kaolinite crust formation, its destruction and fluvial transport.

Similar climatic fluctuations influenced also the marine sediments of the Dudziniec Fm. Sedimentation was periodically influenced by aeolian input, and, intermittently by freshwater input bringing coarse quartz grains and resedimented felsic material. However, there is a lack of kaolinite, and the clay content in the matrix is reduced.

These facts concern the question of the age of the marine transgression at the end of the Triassic. Szulc (in Feist-Burkhard et al., 2008) proposed a mid-Rhaetian transgression in the German Basin. The lithostratigraphy of top Triassic sequence of Alpine-Carpathian shelf does not support this age determination due to the lack (or rarity) of index fossils: the marine Koessen Formation overlies the Plattenkalk in the Alpine Bajuvaric Zone, the Fatra Formation follows the Carpathian Keuper in the Fatric Zone (Michalík et al., 2013). The Hybe and Norovica formations occur on top of the Dachstein Limestone in the Hronic Zone of the Western Carpathians. In all areas, transgression (presumably) started during the mid-Rhaetian. In the southernmost zones only, with a continuous fully marine sequence, Sevatian strata yield a ammonite and conodont fauna (Pálfy et al., 2001; Haas et al., 2010; Csaszár et al., 2013). The marginal Tatric zone may have been flooded somewhat later, but probably before the end of the Triassic (in accordance with the coclusion of Radwański, 1968): it is supported by previous findings of Rhaetian bivalves in the basal limestone layers near to Valaská Belá in the Strážovské Vrchy Mts. (Kochanová in Mahel', 1966). Additional studies such as (palyno- and magnetostratigraphy) are needed to resolve the precise timing of the transgressive event.

\section{CONCLUSIONS}

Despite the truncation of the Triassic/Jurassic sedimentary record by erosive events a detailed study of the Červený Úplaz sequence offers valuable data on palaeoclimate, sedimentary development and palaeogeography of the Tatric Unit in the northernmost part of the Tethyan Domain.

1. The Tomanová Formation is built of shale with a high kaolinite content (kaolinite $\approx$ dioctahedral 2:1 phyllosilicates \pm chlorite), indicating a wet climate during late Rhaetian times consistent with conditions elsewhere across the European continent (Rhaetian-Hettangian kaolinization period). 


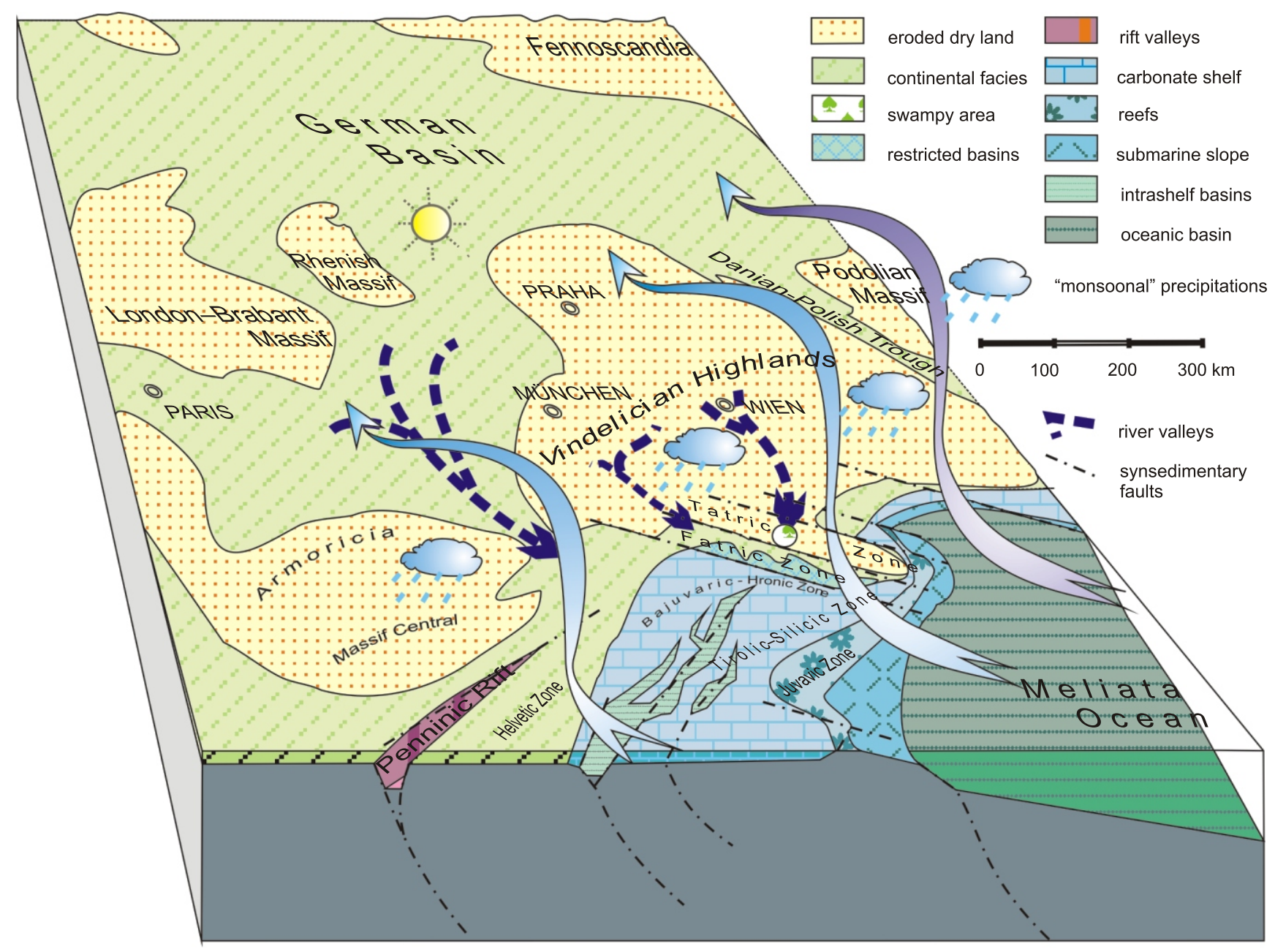

Fig. 17. Palaeogeographic sketch of the northern Mediterranean Tethys shore belt with probable direction of "megamonsoons" and riverine transport during Late Triassic times; adapted from Ziegler (1980), Stampfli et al. (1998), Michalík (2003, 2011), Csontos and Vörös (2004), Feist-Burkhardt et al. (2008), and Berra et al. (2010)

2. Kaolinite crusts of intensely weathered elevated areas were eroded and transported into basins as indicated by lithofacies, by the mineralogical homogeneity of the rock and by its chemical composition. The ratio of kaolinite vs. dioctahedral 2:1 phyllosilicates in the shale indicates changes in the pattern of erosion and sedimentation. The chemical composition indicates a uniform source of strongly weathered felsic rocks.

3. The sandstone layers contain mixed aeolian and fluvial quartz grains with textural immaturity of the sedimentary material. Clastic grains reached mineralogical maturity due to prolonged chemical weathering. The cyclic character (probably $400 \mathrm{kyr}$ eccentricity cycles) of the lithofacies, mineralogy and chemical properties indicate periodic erosion of kaolinite crusts from a distant source area and their transport down river.

4. The sedimention rate $(83 \mathrm{~mm} / \mathrm{kyr}$ according to the cyclostratigraphic analysis) reflect pattern of rainfall. The production and decay of organic matter was controlled by humidity. Chemical elements $(U, V$, and $E u)$ including large Fe inputs with successive siderite and berthierine formation were mobilized by reduced conditions.

5. The characteristic $C$ isotope composition indicates a continental origin of the organic matter. A relative decrease in $\delta^{13} \mathrm{C}_{\text {org }}$ values of the Dudziniec Formation carbonates indicates marine organic matter inputs and, in principle, it documents marine transgression. The stratigraphic distribution and environmental significance of the benthic foraminifera are used to characterize a gradual stabilization of marine biota. Foraminifera indicated a late Rhaetian age.

6. The cycles preserved in these transgressive beds are of similar character as fining upwards parasequences of the Tomanová Formation, being also of long eccentricity type. However, the mineralogy and geochemical indices indicate different sources and transport processes. Their sedimentation rate attained $25 \mathrm{~mm} / \mathrm{ka}$. Values of $\delta^{18} \mathrm{O}$ and $\delta^{13} \mathrm{C}$ in carbonates document meteoric re-equilibration within parasequences.

7. Sands and clays of the Tomanová Formation originated from mechanical and chemical weathering of the Vindelician Highland. Periodical climatic changes ("megamonsoons" from the Tethyan Domain) provided transport of eroded material and enroused palaeosoils formation and bioproductivity in lacustrine basins. Sea-level rise triggered by thermal expansion of the Central Atlantic Rift was gradual in the Tatric region being affected by input of terrestrial clastic sediment both via freshwater and by wind.

Acknowledgments. The authors acknowledge Dr. V. Šimo, of the Geological Institute of the Slovak Academy of Science, Bratislava and Prof. E. Roniewicz from the Institute of 
Palaeobiology of the Polish Academy of Science, Warsaw, for their help in determining the fossils. Prof. J. Szulc, Dr. P. Brański, Prof. A. Goetz are acknowledged for valuable critical remarks and Dr J. Zalasiewicz for careful English correction, which considerably enhanced the quality of the paper. Thanks to R. Milovský, Ph.D., for providing isotope analyses, to Dr. L'. Puškelová for carefull XRD analyses and to Dr. M. Sýkora for lending of thin sections set. We are also indebted to the Administration of the Tatra National Park for permission of entry into the area and for its kind support of field work. This paper originated as a contribution to the VEGA grant projects 0065/2012, 0042/2012 and IGCP 609 (Climate environmental deteriorations during greenhouse phases). It was sponsored by the Operational Programme Research and Development through the project: Centre of Excellence for Integrated Research of the Earth's Geosphere (ITMS: 26220120064), co-financed through the ERDF.

\section{REFERENCES}

Ahlberg A., Andorff L., Guy-Ohlson D. (2002) Onshore climate changes during the Late Triassic marine inundation of the Central European Basin. Terra Nova, 14: 241-248.

Ahlberg A., Olsson I., Šimkevičius P. (2003) Triassic-Jurassic weathering and clay mineral dispersal in basement areas and sedimentary basins of southern Sweden. Sedimentary Geology, 161: $15-29$

Al-Juboury A.l., Ďurovič V. (1992) Paleoenvironment interpretation of the Carpathian Keuper rocks as revealed by clay mineral analysis. Geologica Carpathica, Clays, 2: 73-76.

Andrews J.E. (2006) Palaeoclimate record from stable isotopes in riverine tufas: synthesis and review. Earth-Science Reviews, 75: 85-104.

Andrusov D., Bystrický J., Fusán O. (1973) Outlines of the structures of the West Carpathians. Introductory Excursion Guidebook. X Congress of Carpathian-Balkan Geological Association. Geologický ústav Dionýza Štúra, Bratislava.

Beerling D.J., Royer D.L. (2002) Fossil plants as indicators of the Phanerozoic global carbon cycle. Annual Reviews of Earth and Planetary Sciences, 30: 527-556.

Belcher C.M., Mander L., Rein G., Jervis F.X., Haworth M., Glasspool I.J., Hesselbo S.P., McElwain J.C. (2010) Increased fire activity at the Triassic/Jurassic boundary in Greenland due to climate-driven floral change. Nature Geoscience, 3: 426-429.

Berner R.A., Beerling D.J. (2007) Volcanic degassing necessary to produce a $\mathrm{CaCO}_{3}$ undersaturated ocean at the Triassic-Jurassic boundary. Palaeogeography, Palaeoclimatology, Palaeoecology, 244: 368-373.

Berra F., Jadoul F., Anelli A. (2010) Environmental control on the end of the Dolomia Principale/Hauptdolomit depositional system in the central Alps: Coupling sea-level and climate changes. Palaeogeography, Palaeoclimatology, Palaeoecology, 290: 138-150.

Blackburn T.J., Olsen P.E., Bowring S.A., McLean N.M., Kent D.V., Puffer J., McHone G., Rasbury E.T., El-Touhami M. (2013) Zircon U-Pb geochronology links the End-Triassic Extinction with the Central Atlantic Magmatic Province. Science, 340: 941-945.

Bonis N.R., Ruhl M., Kürschner W.M. (2010) Milankovitch-scale palynological turnover across the Triassic-Jurassic transition at St. Audrie's Bay, SW UK. Journal of Geological Society, 167, 877-888.

Brański P. (2009) Influence of paleoclimate and the greenhouse effect on Hettangian clay mineral assemblages (Holy Cross Mts area, Polish Basin). Geological Quarterly, 53 (3): 363-368.

Bristow T.F., Kennedy M.J., Derkowski A., Droser M.L., Jiang G., Creaser R. (2009) Mineralogical constraints on the paleoenvironments of the Ediacaran Doushantuo Formation. Proceedings of the National Academy of Sciences of the United States of America (PNAS), August 11, 106 (32): 13190-19195.
Cerling T.E., Solomon D. K., Quade J., Bowman J.R. (1991) On the isotopic composition of carbon in soil carbon dioxide. Geochimica et Cosmochimica Acta, 55: 3403-3405.

Chamley H. (1989) Clay Sedimentology. Springer-Verlag, Berlin, Heidelberg.

Condie K.C. (1993) Chemical composition and evolution of the upper continental crust: Contrasting results from surface samples and shales. Chemical Geology, 104: 1-37.

Cohen A.S., Coe A.L. (2007) The impact of the Central Atlantic Magmatic Province on climate and on the Sr- and Os- isotope evolution in seawater. Palaeogeography, Palaeoclimatology, Palaeoecology, 244: 374-390.

Császár G., Szinger B., Piros O. (2013) From continental platform towards rifting of the Tisza Unit in the late Triassic to Early Cretaceous. Geologica Carpathica, 64: 279-290.

Csontos L., Vörös A. (2004) Mesozoic plate tectonic reconstruction of the Carpathian region. Palaeogeography, Palaeoclimatology, Palaeoecology, 210: 1-56.

Cullers R.L. (2000) The geochemistry of shales, siltstones and sandstones of Pennsylvanian-Permian age, Colorado, U.S.A.: implications for provenance and metamorphic studies. Lithos, 51: 305-327.

Dera G., Pelleard P., Neige P., Decomick J-F., Pucéat E. Domergues J.-L. (2009) Distribution of clay minerals in the Early Jurassic Peritethyan sea: Paleoclimatic significance inferred from multiproxy comparison. Palaeogeography, Palaeoclimatology, Palaeoecology, 290: 39-51.

Dudek T., Środoń J. (1996) Identification of illite/smectite by X-ray powder diffraction taking into account the lognormal distribution of crystal thickness. Geologica Carpathica - Clays, 5: 21-32.

Dumont T., Wieczorek J., Bouillin J.P. (1996) Inverted Mesozoic rift structures in the Polish Western Carpathians (High-Tatra units). Comparison with similar features in the Western Alps. Eclogae Geologicae Helvetiae, 89: 181-202.

Eberl D.D. (2003) User's Guide to Rockjock - a program for determining quantitative mineralogy from powder X-ray diffraction data. U.S. Geological Survey Open File Report, 2003: 3-78.

Feist-Burkhardt S., Götz A., Szulc J., Borkhataria R., Geluk M., Haas J., Hornung J., Jordan P., Kempf G., Michalík J., Nawrocki J., Reinhardt L., Ricken W., Röhling H.-G., Rüffer T., Török Á., Zühlke R. ( 2008) Triassic. In: The Geology of Central Europe, 2. Mesozoic and Cenozoic (ed. T. McCann). The Geological Society of London.

Fijałkowska A., Uchman A. (1993) New data on the palynology of the Triassic of the Polish Tatra Mts (in Polish with English summary). Przegląd Geologiczny, 41: 373-375.

Floyd P.A., Leveridge B.E. (1987) Tectonic environments of the Devonian mode and geochemical evidence from turbiditic sandstones. Journal of Geological Society, 144: 531-542.

Galbarczyk-Gąsiorowska L. (2010) REE mobility in the weathering profile - a case study from the Karkonosze Massif (SW Poland). Acta Geologica Polonica, 60: 599-516. 
Garcia D., Fontailles M., Moutte J. (1994) Sedimentary fractionations between $\mathrm{Al}, \mathrm{Ti}, \mathrm{Zr}$ and genesis of strongly peraluminous granites. Journal of Geology, 102: 411-422.

Gaździcki A.(1974) Rhaetian microfacies, stratigraphy and facial development in the Tatra Mts. Acta Geologica Polonica, 24: 17-96.

Gaździcki A., Michalík J., Planderová E., Sýkora M. (1979) An Upper Triassic - Lower Jurassic sequence in the Križna Nappe (West Tatra Mts, Western Carpathians, Czechoslovakia). Západné Karpaty, Geológia, 5: 119-148.

Gingele F.X, Müller, P.M., Schneider R.R. (1998) Orbital forcing of freshwater input in the Zaire Fan area - clay mineral evidence from the last $200 \mathrm{kyr}$. Palaeogeography, Palaeoclimatology, Palaeoecology, 138: 17-26.

Gorek A. (1958) Die geologischen Verhältnisse der Gebirgsgruppe Červené Vrchy, der Täler Tichá und Tomanová. Geologický sborník Slovenskej Akadémie Vied, 9 (2): 203-240.

Götz A.E., Ruckwied K., Barbacka M. (2011) Paleoenvironment of the Late Triassic (Rhaetian) and Early Jurassic (Hettangian) Mecsek Coal Formation (south Hungary): implication from macro and microfloral assemblage. Palaeogeography, Palaeoclimatology, Palaeoecology, 91:75-88.

Haas J., Götz A.E., Pálfy J. (2010) New insight on Late Triassic to early Jurassic paleogeography and eustatic history of the NW Tethyan Realm: implication from sedimentary and organic facies of the Csóvár Basin, Hungary. Palaeogeography, Palaeoclimatology, Palaeoecology, 291: 456-468

Haley B.A., Klinkhammer G.P., MacManus J. (2004) Rare earth elements in pore water of marine sediments. Geochimica et Cosmochimica Acta, 68: 1256-1276.

Hannigan R.E., Sholkovitz E.R. (2001) Rare earth element chemistry of natural waters: chemical weathering and dissolved REE contents in major river systems. Chemical Geology, 175: 495-508.

Hautmann M. (2004) Effect of end-Triassic $\mathrm{CO}_{2}$ maximum on carbonate sedimentation and marine mass extinction. Facies, 50: 257-261.

Hesselbo S.P., Robinson S.A., Surlyk F., Piasecki S. (2002) Terrestrial and marine extinction at the Triassic-Jurassic boundary synchronized with major carbon-cycle perturbation: a link to initiation of massive volcanism? Geology, 30: 251-254.

Heimhofer U., Adatte T., Hochuli P.A., Burla S., Weissert H. (2008) Coastal sediments from the Algarve: low-latitude climate archive for Aptian-Albian. International Journal of Earth Sciences, 97: 785-797.

Hillier S. (1994) Pore-lining chlorites in siliciclastic reservoir sandstones: electron microprobe, SEM and XRD data, and implications for their origin. Clay Minerals, 29: 665-679.

Honty M., Clauer N., Šucha V. (2008) Rare-earth elemental systematics of mixed-layered illite-smectite from sedimentary and hydrotherme environments of the Western Carpathians (Slovakia). Chemical Geology, 249: 167-190.

Hornibrook E.R.C., Longstaffe F.J. (1996) Berthierine from the lower Cretaceous Clearwater formation, Alberta, Canada. Clays and Clay Minerals, 44: 1-21.

Hori R.S., Fujiki T., Inoue E., Kimura J.I. (2007) Platinum group element anomalies and bioevents in the Triassic-Jurassic deep-sea sediments of Panthalassa. Palaeogeography, Palaeoclimatology, Palaeoecology, 244: 391-406.

Huynh T.T., Poulsen C.J. (2005) Rising atmospheric $\mathrm{CO}_{2}$ as a possible trigger for the end-Triassic mass extinction. Palaeogeography, Palaeoclimatology, Palaeoecology, 217: 1-21.

Jaglarz P. (2010) Facies and sedimentary environment of the carbonate-dominated Carpathian Keuper from the Tatricum domain: Results from the Dolina Smytnia Valley (Tatra Mts., Southern Poland). Annales Societatis Geologorum Poloniae, 80: 147-161.

Jaglarz P., Szulc J. (2003) Middle Triassic evolution of the Tatricum sedimentary basin: An attempt of sequence stratigraphy to the Wierchowa Unit in the Polish Tatra Mountains. Annales Societatis Geologorum Poloniae, 73: 169-182.
Jorissen F.J., Stigter H.C. de, Widmark J.G.V. (1995) A conceptual model explaining benthic foraminiferal microhabitats. Marine Micropaleontology, 26: 3-15.

Kisch H.J. (1983) Mineralogy and petrology of burial diagenesis (burial metamorphism) and incipient metamorphism in clastic rocks. Developments in Sedimentology, 25B: 289-493.

Kotański Z. (1959) Stratigraphy, sedimentology and paleogeography of the high-Tatric Triassic in the Tatra Mts. Acta Geologica Polonica, 9: 113-145.

Kotański Z. (1961) Tectogénèse et reconstitution de la paléogéographie de la zone haut-tatrique dans les Tatras (in Polish with French summary). Acta Geologica Polonica, 11 187-476.

Kotański Z. (1979) The position of the Tatra Mts. in the western Carpathians (in Polish with English summary). Przegląd Geologiczny, 27: 359-369.

Kozur H. (1991) The evolution of Meliata-Hallstatt Ocean and its significance for early evolution of the Eastern Alps and Western Carpathians. Palaeogeography, Palaeoclimatology, Palaeoecology, 8: 109-135.

Kraus I. (1989) Kaolins and kaolinite clays (in Slovak). Západné Karpaty, séria Mineralógia, Petrografia, Geochémia, Metalogenéza, 13: 7-287.

Kuerschner W.M., Bonis N.R., Krystyn L. (2007) Carbon-isotope stratigraphy and palynostratigraphy of the Triassic-Jurassic transition in the Tiefengraben section - Northern Calcareous Alps (Austria). Palaeogeography, Palaeoclimatology, Palaeoecology, 244: 257-280.

Lanson B., Beaufort D., Berger G., Bauer A., Cassagnabére Meunier A. (2001) Authigenic kaolin and illitic minerals during burial diagenesis of sandstones: a review. Clay Minerals, 37: $1-22$.

Lefeld J., Gaździcki A., Iwanow A., Krajewski K., Wójcik K. (1985) Jurassic and Cretaceous lithostratigraphic units of the Tatra Mountains. Studia Geologica Polonica, 84: 3-93.

Lucas S.G., Tanner L.H. (2007) Tetrapod biostratigraphy and biochronology of the Triassic-Jurassic transition on the southern Colorado Plateau, USA. Palaeogeography, Palaeoclimatology, Palaeoecology, 244: 242-256.

Lund J.J. (1977) Rhaetic to Lower Liassic palynology of the onshore south-eastern North Sea Basin. Danmarks Geologiske Undersøgelse, 2nd Series, 109: 1-129.

MacRae N.D., Nesbitt H.W., Kronberg B.I. (1992) Development of a positive Eu anomaly during diagenesis. Earth and Planetary Science Letters, 109: 585-591.

Mahel' M., ed. (1966) Regional Geology of Czechoslovakia II, Western Carpathians, pt. 1. Academia Praha.

McElwain J.C., Punyasena S.W. (2007) Mass extinction events and the plant fossil record. Trends in Ecology and Evolution, 22: 10-11.

McElwain J.C., Popa M.E., Hesselbo S.P., Haworth M., Surlyk F. (2007) Macroecological response of terrestrial vegetation to climatic and atmospheric change across the Triassic/Jurassic Boundary in East Greenland. Paleobiology, 33: 547-573.

McElwain J.C., Wagner P.J., Hesselbo S.P. (2009) Fossil plant relative abundance indicate sudden loss of Late Triassic biodiversity in East Greenland. Science, 324: 1554-1556.

McLennan S.M. (1993) Weathering and global denudation. Journal of Geology, 101: 295-303.

McLennan S.M., Hemming S., McDaniel D.K., Hanson G.N. (1993) Geochemical approaches to sedimentation, provenance and tectonics. GSA Special Paper, 248: 21-40.

McRoberts C.A. (1994) The Triassic-Jurassic ecostratigraphic transition in the Lombardian Alps, Italy. Palaeogeography, Palaeoclimatology, Palaeoecology, 110: 145-166.

McRoberts C.A., Furrer H., Jones D.S. (1997) Palaeoenvironmental interpretation of a Triassic-Jurassic boundary section from Western Austria based on palaeoecological and geochemical data. Palaeogeography, Palaeoclimatology, Palaeoecology, 136: 79-95. 
Michalík J. (1977) Paläogeographische Untersuchungen der Fatra Schichten (Kössen Formation) der nördlichen Teiles des Fatrikums in der Westkarpaten. Geologický zborník Geologica Carpathica, 28: 71-94,

Michalík J. (1993) Mesozoic tensional basins in the Alpine-Carpathian shelf. Acta Geologica Hungarica, 36: 395-403.

Michalík J. (1994) Notes on the paleogeography and paleotectonics of the Western Carpathian area during the Mesozoic. Mitteilungen der Österreichischen Geologischen Gesellschaft, 86: 101-110.

Michalík J. (2007) Sedimentary rock record and microfacies indicators of the latest Triassic to mid-Cretaceous tensional development of the Zliechov Basin (Central Western Carpathians). Geologica Carpathica, 58: 443-453.

Michalík J. (2011) Mesozoic paleogeography and facies distribution in the Northern Mediterranean Tethys from Western Carpathians view. Iranian Journal of Earth Sciences, 3: 185-193.

Michalík J., ed. (2003) Triassic/Jurassic Boundary Events. Special Volume to the 3th Annual Workshop of the 458 (TRIBE) IGCP UNESCO Project, Stará Lesná, October 2003, VEDA Bratislava.

Michalík J., Planderová E., Sýkora M. (1976) To the stratigraphic and paleogeographic position of the Tomanová Formation in the uppermost Triassic of the West Carpathians. Geologický Zborník Geologica Carpathica, 27: 299-318.

Michalík J., Kátlovský V., Hluštík A. (1988) Plant remains in the Tomanová Formation (uppermost Triassic, West Carpathians): their origin, composition and diagenetic alteration. Geologický Zborník Geologica Carpathica, 39: 523-537.

Michalík J., Lintnerová O., Gaździcki A., Soták J. (2007) Record of environmental changes in the Triassic-Jurassic boundary interval in the Zliechov Basin, Western Carpathians. Palaeogeography, Palaeoclimatology, Palaeoecology, 244: 71-88.

Michalík J., Biroň A., Lintnerová O., Götz A.E., Ruckwied K. (2010) Climatic change at the T/J boundary in the NW Tethyan Realm (Tatra Mts, Slovakia). Acta Geologica Polonica, 60: 535-548.

Michalík J., Lintnerová O., Wójcik-Tabol P., Gaździcki A., Grabowski J., Golej M., Šimo V., Zahradníková B. (2013) Paleoenvironments during the Rhaetian transgression and the colonization history of marine biota in the Fatric Unit (Western Carpathians). Geologica Carpathica, 64: 39-62.

Mongelli G., Critelli S., Perri F., Sonnino M., Perrone V. (2006) Sedimentary recycling, provenance and paleoweathering from chemistry and mineralogy of Mesozoic continental redbed mudrocks, Peloritani Mts, southern Italy. Chemical Journal, 40: 197-209.

Moore D.M., Reynolds R.C. Jr. (1997) X-Ray diffraction and the identification and analysis of clay minerals, second edition. Oxford University Press, USA.

Morad S., Ketzer J.M., Ros L.F. de (2000) Spatial and temporal distribution of diagenetic alterations in siliciclastic rocks: implication for mass transfer in sedimentary basins. Sedimentology, 47: 95-120.

Murray R.W., Buchholtz ten Brink M.R., Gerlach D.C., Russ G.R. III., Jones D.L. (1992) Interoceanic variation in the rare earth, major and trace element depositional chemistry of cherts: Perspective gained from DSDP and ODP record. Geochimica et Cosmochimica Acta, 56: 1897-1913.

Nagy J., Hess S., Alve E. (2010) Environmental significance of foraminiferal assemblages dominated by small-sized Ammodiscus and Trochammina in Triassic and Jurassic delta-influenced deposits. Earth-Science Reviews, 99: 31-49.

Nagy J., Hess S., Dypvik H., Bjćrke T. (2011) Marine shelf to paralic biofacies of Upper Triassic to Lower Jurassic depositsin Spitsbergen. Palaeogeography, Palaeoclimatology, Palaeoecology, 300: 138-151.

Nesbitt H.W., Markovics G. (1997) Weathering of the granodioritic crust, long-term storage in the weathering profiles and petrogenesis of siliciclastic sediments. Geochimica et Cosmochimica Acta, 61: 1653-1670.
Nesbitt H.W., Young G.M. (1984) Prediction of some weathering trends of plutonic and volcanic rocks based on thermodynamic and kinetic consideration. Geochimica et Cosmochimica Acta, 48: $1523-1534$.

Nesbitt H.V., McRae N.D., Kronberg B.I. (1990) Amazon deep-sea muds: light REE enriched products of extreme chemical weathering. Earth and Planetary Science Letters, 100: 18-123.

Niedźwiedzki G. (2005) A new find of dinosaur footprints in the Upper Triassic of the Tatra Mountains, southern Poland (in Polish with English summary). Przegląd Geologiczny, 53: 410-413.

Niedźwiedzki G. (2011) A Late Triassic dinosaur-dominated ichnofauna from the Tomanová Formation of theTatra Mts, central Europe. Acta Palaeontologica Polonica, 58: 291-300.

Odin G.S., Knox R.W., Gygi R.A., Guerrak S. (1988) Green marine clays from the oolitic ironstone facies: habit, mineralogy, environment. Developments in Sedimentology, 45: 29-52.

Ohta T., Arai H. (2007) Statistical empirical index of chemical weathering in igneous rocks: A new tool for evaluating the degree of weathering. Chemical Geology, 240: 280-297.

Olóriz F., Reolid M., Rodríguez-Tovar F.J. (2003) Palaeogeographic and stratigraphic distribution of mid-late Oxfordian foraminiferal assemblages in the Prebetic Zone. Geobios, 36 733-747.

Ounis A., Koczis L., Chaabani F., Pfeifer H.R. (2008) Rare earth elements and stable isotope geochemistry $\left(\delta^{13} \mathrm{C}\right.$ and $\left.\delta^{18} \mathrm{O}\right)$ of phosphorite deposits in the Gafsa Basin, Tunisia. Palaeogeography, Palaeoclimatology, Palaeoecology, 268: 1-18.

Pálfy J., Demény A., Haas J., Hetényi M., Orchard M.J., Vetö I. (2001) Carbon isotope anomaly and other geochemical changes at the Triassic/Jurassic boundary from a marine section in Hungary. Geology, 29: 1047-1050.

Petersen H.I., Lindstöm S. (2012) Synchronous wildfire activity rise and mire deforestation at the Triassic-Jurassic boundary. Plos One, 7 (10): 1-15

Pollastro R.M. (1993) Considerations and applications of the illite/smectite geothermometer in hydrocarbon-bearing rocks of Miocene to Mississippian age. Clays and Clay Minerals, 41: 119-133.

Preto N., Kustatscher E., Wignall P.B. (2010) Triassic climate state of the art and the perspectives. Palaeogeography, Palaeoclimatology, Palaeoecology, 290: 1-10.

Price J.R., Velbel M. (2003) Chemical weathering indices applied to weathering profiles developed on heterogenous felsic metamorphic parent rocks. Chemical Geology, 202: 397-416.

Prochnow S.J, Nordt L.C., Atchley S.C., Hudec M.R. (2006) Multi-proxy paleosol evidence for middle and late Triassic climate trends in eastern Utah. Palaeogeography, Palaeoclimatology, Palaeoecology, 232: 53-72.

Rabowski F. (1959) Tatric series in western Tatra Mts. (in Polish). Prace Instytutu Geologicznego, 27: 5-178.

Raciborski M. (1890) Rhaetic flora in the Tatra Mts. (in Polish) Rozprawy Wydziału Matematyczno-Przyrodniczego, Akademia Umiejętności Kraków, 21: 243-260.

Radwański A. (1968) Petrographical and sedimentological study of the high-Tatric Rhaetic in the Tatra Mts. (in Polish with English summary). Studia Geologica Polonica, 25: 1-146

Reolid M., Martínez-Ruiz F. (2012) Comparison of benthic foraminifera and geochemical proxies in shelf deposits from the Upper Jurassic of Prebetic (southern Spain). Journal of Iberian Geology, 38: 449-465

Reolid M., Nagy J., Rodríguez-Tovar F., Olóriz F. (2008) Foraminiferal assemblages as palaeoenvironmental bioindicators in Late Jurassic epicontinental platforms: relation with trophic conditions. Acta Palaeontologica Polonica, 53: 705-722.

Retallack J.G. (2009) Refining and pedogenic carbonate $\mathrm{CO}_{2}$ paleobarometer to quantify a Middle Miocene greenhouse spike. Palaeogeography, Palaeoclimatology, Palaeoecology, 281 57-65.

Righi D., Meunier A. (1995) Origin of clays by rock weathering and soil formation. In: Velde B. (ed.): Origin and Mineralogy of Clays. Springer, 43-161. 
Ruckwied K., Götz A.E. (2009) Climate change at the Triassic/Jurassic boundary: Palynological evidence from the Furkaska section (Tatra Mountains, Slovakia). Geologica Carpathica, 60: 139-149.

Ruckwied K., Götz A.E., Pálfy J., Török Á. (2008) Palynology of a terrestrial coal-bearing series across the Triassic/Jurassic boundary (Mecsek Mts, Hungary). Central European Geology, 51: 1-15.

Ruffell A., McKinley J.M., Worden R.H. (2002) Comparison of clay mineral stratigraphy to other palaeoclimate indicators in the Mesozoic of NW Europe. Philosophical Transaction of the Royal Society of London, A 360: 675-693.

Ruhl M., Veld H. W.M., Kürschner W.M. (2010) Sedimentary organic matter characterization of the Triassic-Jurassic boundary GSSP at Kuhjoch (Austria). Earth and Planetary Science Letters, 292: 17-26.

Ruhl M., Bonis N.R., Reichart G.J., Damsté J.S.S., Kürschner W.M. (2011) Atmospheric carbon injection linked to end-Triassic mass extinction. Science, 333: 430-434.

Rychliński T. (2008) Facies development and sedimentary environments of the Carpathian Keuper deposits from the Tatra Mts., Poland and Slovakia. Annales Societatis Geologorum Poloniae, 78: $1-18$.

Schulte P., Geldern R. van, Freitag H., Karim A., Petelet-Giraud P.N.E., Probst A., Probst J.L., Telmer K., Veizer J., Barth J.A.B. (2011) Applications of stable water and carbon isotopes in watershed research: Weathering, carbon cycling, and water balances. Earth-Science Reviews, 109: 20-31.

Sha J., Vajda V., Pan Y., Larsson L., Yao X., Zhang X., Wang Y., Cheng X., Jiang B., Deng Sh., Chen S., Peng B. (2011) Stratigraphy of the Triassic-Jurassic succession of the $S$ margin of the Junggar Basin, NW China. Acta Geologica Sinica, 85: 421-436.

Sheldon N.D., Tabor N.J. (2009) Quantitative paleoenvironmental and paleoclimatic reconstruction using paleosols. Earth-Science Reviews, 95: 1-52.

Shields G., Webb G.E. (2004) Has the REE composition of seawater changed over geological time? Chemical Geology, 204: 103-107.

Shutov V.D., Aleksandrova A.V., Losievskaya S.A. (1970) Genetic interpretation of the polymorphism of the kaolinite group in sedimentary rocks. Sedimentology, 15: 69-82.

Smith J.R., Giegengack R., Schwarcz H.P. (2004) Constraints on Pleistocene pluvial climates through stable-isotope analysis of fossil spring tufas and associated gastropods, Kharga Oasis, Egypt. Palaeogeography, Palaeoclimatology, Palaeoecology, 206: 157-175.

Środoń J., Eberl D.D. (1984) Reviews in Mineralogy, 13: 495-544.

Środoń J., Drits V.A., McCarty D.K., Hsieh J.C.C., Eberl D.D. (2001) Quantitative X-ray diffraction analysis of clay-bearing rocks from random preparations. Clays and Clay Minerals, 49: 514-528.

Środoń J., Kotarba M., Biroň A., Such P., Clauer N., Wójtowicz A. (2006) Diagenetic history of the Podhale-Orava Basin and the underlying Tatra sedimentary structural units (Western Carpathians): Evidence from XRD and K-Ar of illite-smectite. Clay Minerals, 41: 751-774.

Stampfli G.M., Mosar J., Bono A. de, Vavasis I. (1998) Late Paleozoic, early Mesozoic plate tectonics of the Western Tethys. Bulletin of the Geological Society of Greece, 31: 113-120.

Šucha V., Środoń J., Zatkalíková V., Franců J. (1991) Mixed layered illite/smectite: separation, identification, use (in Slovak with English abstract). Mineralia Slovaca, 23: 267-274.

Šucha V., Kraus I., Gerthofferová H., Peteš J., Sereková M. (1993) Smectite to illite conversion in bentonites and shales of the East Slovak basin. Clay Minerals, 28: 243-253.

Taylor S.R. McLennan S.M. (1985) The Continental Crust: its Composition and Evolution. Blackwell Oxford.

Tyszka J. (1994) Response of Middle Jurassic benthic foraminiferal morphogroups to dysoxic/anoxic conditions in the Pieniny Klippen Basin, Polish Carpathians. Palaeogeography, Palaeoclimatology, Palaeoecology, 110: 55-81.

Tyszka J. (2001) Microfossil assemblages as bathymetric indicators of the Toarcian/Aalenian „Fleckenmergel" facies in the Carpathian Pieniny Klippen Belt. Geologica Carpathica, 52: 147-158.

Uhlig V. (1897) Geologie der Tatragebirges I. Einleitung und der stratigraphisches Theil. Anzeiger der Akademische Wissenschaften, Mathematisch-Naturwissenschafliche Klasse, 64: 643-684.

Vd’ačný M., Vozárová A., Vozár J. (2013) Geochemistry of the Permian sandstone from the Malužiná Formation in the Malé Karpaty Mts (Hronic Unit, Western Carpathians, Slovakia). Geologica Carpathica, 64: 23-38.

Ward P.D., Garrison G.H., Haggart J.W., Kring D.A., Beattie M.J. (2004) Isotopic evidence bearing on Late Triassic extinction events, Queen Charlotte Islands, British Columbia, and implications for the duration and cause of the Triassic/Jurassic mass extinction. Earth and Planetary Science Letters, 224: 589-600.

Ward P.D., Garrison G.H., Williford K.H., Kring K.H., Goodwin D., Beattie M., McRoberts C. (2007) The organic carbon isotopic and paleontological record across the Triassic-Jurassic boundary at the candidate GSSP section at Fergusson Hill, Muller Canyon, Nevada, USA. Palaeogeography, Palaeoclimatology, Palaeoecology, 244: 281-289

Weaver C.E. (1989) Clays, Muds, and Shales. Elsevier, Developments in Sedimentology, 44: 1-819.

White T., Gonzalez L., Ludvigson G., Poulsen C. (2001) Middle Cretaceous greenhouse hydrologic cycle of North America. Geology, 29: 363-366.

Zajzon N., Kristály F., Pálfy J., Németh T. (2012) Detailed clay mineralogy of the Triassic-Jurassic boundary section at Kendelbachgraben (Northern Calcareous Alps, Austria). Clay Minerals, 47: 177-189.

Ziegler P.A. (1980) Northwestern Europe: subsidence patterns of Post-Variscan Basins. Mémoires BRGM, 108: 249-280. 